\title{
Nutritional modulation of exercise-induced immunodepression in athletes: a systematic review and meta-analysis
}

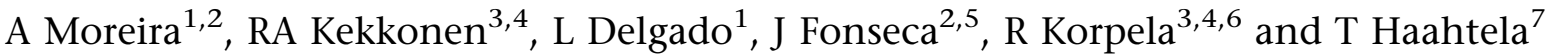 \\ ${ }^{1}$ Laboratory of Immunology, Faculty of Medicine, University of Porto, Porto, Portugal; ${ }^{2}$ Immuno-allergology, Hospital of São João, \\ Porto, Portugal; ${ }^{3}$ Institute of Biomedicine, University of Helsinki, Helsinki, Finland; ${ }^{4}$ Valio Ltd, R\&D, Helsinki, Finland; ${ }^{5}$ Biostatistics \\ and Medical Informatics, Faculty of Medicine, University of Porto, Porto, Portugal; ${ }^{6}$ Foundation for Nutrition Research, Helsinki, \\ Finland and ${ }^{7}$ Skin and Allergy Hospital, Helsinki University Central Hospital, Helsinki, Finland
}

Background: Heavy exercise induces marked immunodepression that is multifactorial in origin. Nutrition can modulate normal immune function.

Objective: To assess the efficacy of nutritional supplements in exercise-induced immunodepression in athletes.

Design: Systematic review.

Review methods: Randomised and/or controlled trials of athletes undertaking nutritional supplements to minimise the immunodepression after exercise were retrieved. The primary outcome measure was incidence of upper respiratory tract (URT) illness symptoms after exercise, and secondary outcomes included cortisol, cell counts, plasma cytokine concentration, cell proliferative response, oxidative burst, natural killer cell activity and immunoglobulins. When data were available for a pooled estimate of the effect of intervention, meta-analyses were conducted for direct comparisons.

Results: Forty-five studies were included (1603 subjects). The studies were heterogeneous in terms of exercise interventions, selection of athletes, settings and outcomes. The overall methodological quality of most of the trials was poor. Twenty studies addressed carbohydrate supplementation, eight glutamine, 13 vitamin $C$ and four others interventions. Three trials assessed the effect of intervention on prevention of URT infections. The pooled rate ratio for URT infections after vitamin $C$ supplementation against placebo was $0.49(0.34-0.71)$. Carbohydrate supplementation attenuated the increase in cortisol and neutrophils after exercise; vitamin $C$ attenuated the decrease in lymphocytes after exercise. No other interventions had significant or consistent effect on any of the studied outcomes.

Conclusions: Although the prevention of URT infections by vitamin C was supported by two trials, further studies are needed. The available evidence failed to support a role for other nutritional supplements in preventing exercise-induced immune suppression. Larger trials with clinically relevant and uniform end points are necessary to clarify the role of these nutritional interventions.

European Journal of Clinical Nutrition (2007) 61, 443-460. doi:10.1038/sj.ejcn.1602549; published online 29 November 2006

Keywords: athletes; sports; infections; exercise-induced immunodepression; systematic review; immune function

Correspondence: Dr A Moreira, Laboratory of Immunology, Faculty of Medicine, University of Porto, Al. Prof. Hernâni Monteiro, 4202 Porto, Portugal.

E-mail: andremoreira@med.up.pt

Guarantor: A Moreira.

Contributors: TH, AM, LD contributed to the conception and design of the study. AM and JF were responsible for data acquisition. All the authors contributed to interpretation of results. AM drafted the article. All authors approved the final version for publication.

Received 2 September 2005; revised 8 August 2006; accepted 14 August 2006; published online 29 November 2006

\section{Background}

In contrast to moderate or intermittent physical activity, prolonged and intensive exertion causes numerous changes in immunity that reflect physiological stress and suppression. Athletes undertaking regular strenuous exercise are at increased risk of upper respiratory tract (URT) infection during periods of heavy exercise and for 2 weeks following race events (Peters and Bateman, 1983; Peters, 1990). It has been suggested that the relationship between exercise and 
URT infections follows a 'J' curve, with moderate and regular exercise improving the ability to resist infections (Nieman et al., 1993, 1998b, 2004) and heavy acute or chronic exercise decreasing it (Nieman et al., 1990; Nieman, 1994; Castell et al., 1996). The evidence has shown that prolonged periods of intense training may lead to high numbers of neutrophil and low numbers of lymphocytes in blood counts (Nieman et al., 1995, 1998a; Pedersen et al., 1997), impaired phagocytosis (Nieman et al., 1997a) and neutrophilic function (Nieman et al., 2000a), decreased oxidative burst activity (Nieman et al., 1997a), natural killer cell cytolytic activity (NKCA) (Shinkai et al., 1993; Nieman, 1997) and mucosal immunoglobulin levels (Nieman et al., 2002a). Intense training or endurance exercise may also enhance release of pro-inflammatory cytokines such as tumour necrosis factor alfa (TNF-alfa), interleukin-1b (IL-1b) and interleukin-6 (IL-6), followed closely by anti-inflammatory cytokines, such as interleukin-10 (IL-10) and interleukin-1 receptor antagonist (IL-1ra) (Castell et al., 1997; Nieman et al., 2001).

The research on the relationship between nutrition and sport has been focused mainly on the role of dietary nutrients as ergogenic aids. The concept of 'immunonutrition' (Grimble, 2001) and more recently the concept of 'functional foods' (Contor, 2001) refers to the ability of certain nutrients to modulate immune status if they are provided in sufficient amounts, in general far more often in excess of the usual nutritional requirements. Because many nutrients are involved in energy metabolism and protein synthesis, they can modulate immune cell activity and function. Potential mechanisms of action include the ability of the cells to proliferate and differentiate, the production of proteins with specific functions, including chemokines, cytokines or antibodies, phagocytic activity, immune cell mediated immunity and complement formation and activity.

Non-systematic review articles on the efficacy of nutritional interventions in modulating exercise-induced immunodepression recommend that athletes eat a balanced diet that meets their energy requirements and ensures adequate intake of protein and micronutrients (Gleeson et al., 2001, 2004). Besides the consumption of carbohydrates before and during exercise, no clear benefit from any nutritional intervention has appeared in the literature. We are not aware of any systematic reviews relating nutritional interventions in athletes to exercise-induced immune deppression.

\section{Objectives}

The focus of this review is the effects of nutritional supplements on exercise-induced immunological changes in competitive athletes.

\section{Methods}

Randomised controlled trials were identified by searching the following data sources: SPORTDiscus (1975 to May
2005), EBM Reviews - Cochrane Central Register of Controlled Trials 2nd Quarter 2005, EBM Reviews Cochrane Database of Systematic Reviews 2nd Quarter 2005, Ovid MEDLINE(R) In-Process \& Other Non-Indexed Citations and Ovid MEDLINE(R) (1966 to May 2005) and reference lists. The first two levels of the optimal search strategy (Robinson and Dickersin, 2002) were combined with the following subject-specific search terms: 'exercise', 'immune', 'nutrition', 'athletes', 'glutamine', 'carbohydrate', 'vitamin', 'probiotic', 'protein'. Further details of the search strategy are given in Appendix A. The reference lists of all primary studies were reviewed to identify trials not retrieved by the electronic and manual searches. All of the titles and abstracts that were identified by the search and that appeared relevant were selected for a full text review. No restrictions for language were imposed. One hundred and thirty-one publications were identified as potentially relevant. Two investigators (AM, JF) applied the inclusion criteria independently, and where disagreements occurred, they were resolved by consensus. The full text of each paper was obtained. All studies that appeared initially to meet the inclusion criteria, but on closer examination failed to, are detailed in the table of excluded studies (Table 1). From these, 45 were suitable for inclusion (Tables 2-5).

\section{Description of the studies}

We included randomised or placebo-controlled trials of athletes undertaking nutritional supplements to minimise immunodepression after exercise.

\section{Criteria for considering studies for the review}

\section{Participants}

Healthy, competitive athletes or well-trained sportsmen or women, performing acute strenuous exercise. No restrictions for sex or age were made.

\section{Intervention}

We considered all studies reporting on efforts to minimize physiological immunodepression after exercise by means of nutritional intervention (e.g., with glutamine, carbohydrates (CHO), vitamins or antioxidants).

\section{Outcome measures}

The primary outcome measure was URT infections, while secondary outcomes included immunological host resistance measures such as differential cell counts (lymphocytes/neutrophils); plasma cytokines concentrations; blood mononuclear cells (BMNC)/ lymphocyte proliferative response; oxidative burst/phagocytic activity; NKCA; immunoglobulins. 
Table 1 Characteristics of excluded studies

\begin{tabular}{|c|c|c|c|c|c|}
\hline Study reference & Participants and exercise & Supplementation & Outcomes & Results & $\begin{array}{l}\text { Reason for } \\
\text { exclusion }\end{array}$ \\
\hline Gleeson et al. (1998) & $\begin{array}{l}12 \text { untrained males; cycling for } \\
60 \text { min at } 70 \% \text { of maximal } \\
\text { oxygen uptake on two separate } \\
\text { occasions, } 3 \text { days apart }\end{array}$ & $\begin{array}{l}\text { High } \mathrm{CHO} \text { diet } \\
(75 \pm 8 \% \mathrm{CHO}) \text { vs } \\
\text { a low } \mathrm{CHO} \text { diet } \\
(7 \pm 4 \% \mathrm{CHO})\end{array}$ & $\begin{array}{l}\text { Cortisol } \\
\text { Glutamine } \\
\text { Neutrophils }\end{array}$ & $\begin{array}{l}\text { The low-CHO diet was associated } \\
\text { with a larger rise in cortisol, } \\
\text { greater fall in glutamine, and a } \\
\text { larger neutrophilia }\end{array}$ & $\begin{array}{l}\text { Subjects were } \\
\text { untrained males }\end{array}$ \\
\hline Pedersen et al. (2000) & $\begin{array}{l}20 \text { men; endurance training } \\
\text { performed 3-4 times a week for } \\
7 \text { weeks }\end{array}$ & $\begin{array}{l}\text { CHO-rich diet vs } \\
\text { fat-rich diet }\end{array}$ & $\begin{array}{l}\text { Lymphocyte } \\
\text { subsets } \\
\text { NK cell activity }\end{array}$ & $\begin{array}{l}\text { No effect on the percentages of } \\
\text { CD3 }+, C D 4+, C D 8+, C D 19+ \\
\text { or CD14 }+ \text { cells. } \\
\text { NK-cell activity increased in the } \\
\text { group on the carbohydrate-rich } \\
\text { diet and decreased in the group } \\
\text { on the fat-rich diet }\end{array}$ & $\begin{array}{l}\text { Subjects were } \\
\text { untrained males }\end{array}$ \\
\hline Bishop et al. (2001a) & $\begin{array}{l}9 \text { males; cycled at } 75 \% \mathrm{VO}_{2} \max \\
\text { until fatigue }\end{array}$ & $\begin{array}{l}\mathrm{CHO}(5 \% \mathrm{w} / \mathrm{v}) \\
\text { beverage } \\
\text { ingestion before } \\
\text { and at } 15 \text { min } \\
\text { intervals during } \\
\text { the exercise }\end{array}$ & $\begin{array}{l}\text { Cortisol } \\
\text { Cell counts } \\
\text { LPS-stimulated } \\
\text { neutrophil } \\
\text { degranulation }\end{array}$ & No effects & $\begin{array}{l}\text { Subjects were } \\
\text { untrained males }\end{array}$ \\
\hline
\end{tabular}

Abbreviations: BCAA-branched chain amino acid; CHO- carbohydrate; ConA: concavalin A; IL: interleukin; INF: interferon; LPS-Lipopolysaccharide; NK-natural killer; PLA-placebo; SG-supplemented group; TNF: tumoral necrosis factor; URT- Upper-respiratory-tract ; PBMC-peripheral blood mononuclear cells.

\section{Studies}

Both controlled and randomised clinical trials involving at least one test treatment and one control treatment, concurrent enrolment, follow-up of both the test-treated and the control-treated groups, and in which the intervention was selected by a random process.

\section{Quality assessment of included studies and data extraction}

Two reviewers assessed the trials for inclusion by looking at the Methods section of each paper while remaining unaware of the study's results, conclusion and authors. Furthermore, each reviewer independently applied written inclusion criteria to the Methods section of each study to determine the adequacy of subject randomisation, blinding, baseline comparability, outcome measures and the handling of withdrawals/dropouts.

The methodological quality of the included trials was assessed with particular emphasis on allocation concealment and randomisation, which was ranked using the Cochrane Collaboration approach. This led to each trial being attributed a quality score out of a maximum of 17 points (see Appendix B). Trial data were extracted by one reviewer and checked by another. We asked six researchers to provide additional information on trial methodology (method of randomisation) and results (usually requests for data not presented in the original reports).

\section{Quantitative data synthesis}

When data were available for a pooled estimate of the impact of intervention, it was intended that meta-analyses would be conducted for direct comparisons. Effect of interventions on the incidence of URT infections after exercise in athletes was summarised as rate ratios (relative risks) and pooled using the DerSimonian and Laird random-effects model. Effect measures are presented with 95\% confidence intervals. We have presented weighted mean differences (WMD) and 95\% confidence intervals for continuous outcomes for each randomised controlled trial and analysed them in relevant subgroups according to the specific nutritional intervention used. In order to determine whether combining the results was appropriate, a heterogeneity test $\left(\chi^{2}\right.$ statistic) was performed. We used a fixed-effects model to estimate the pooled effect when no evidence of heterogeneity was detected (Whitehead and Whitehead, 1991). However, if evidence of heterogeneity was found to be present, we used a random-effects model (DerSimonian and Laird, 1986). Analysis and forest plots were produced using RevMan 4.2.5 software (2004). The final manuscript was reviewed by the members of $\mathrm{Ga}^{2}$ len involved in the 'Sports, Allergy and Asthma' Work Package.

\section{Results}

\section{Selection of trials}

We included 45 studies, comprising six distinct intervention arms (namely, with carbohydrates, vitamins or antioxidants, glutamine or branched-chain amino acids, plant sterols, polyunsaturated fatty acids and bovine colostrum) that include a total of 1603 subjects (1049 in intervention groups, 544 in placebo groups plus 10 in a crossover design) from four sports activity categories: swimmers, runners, cyclists and football players. A flow chart of studies assessed and excluded at various stages of the review is provided in 
Table 2 Glutamine supplementation studies included in the systematic review

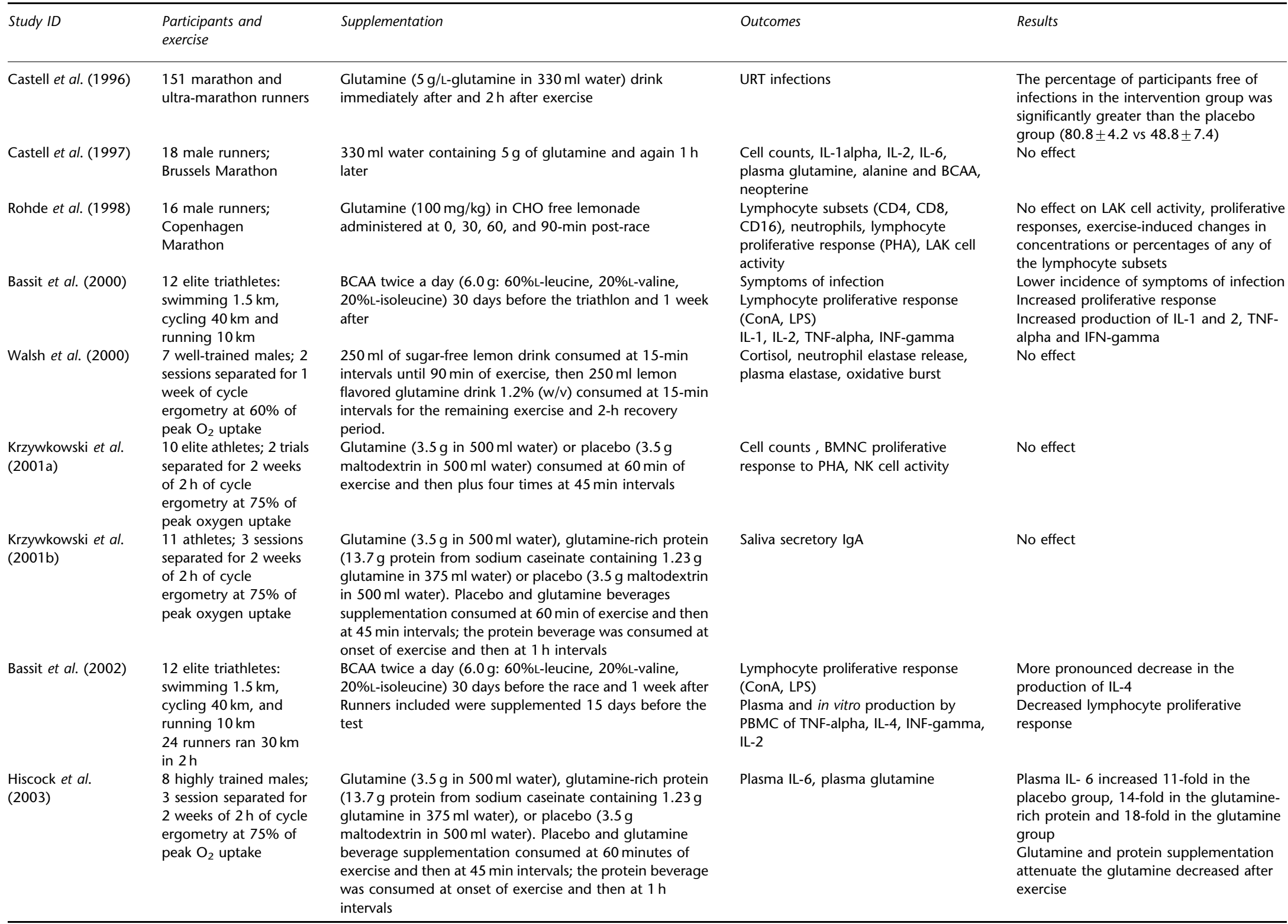
intervals

Abbreviations: BMNC- blood mononuclear cells; CHO, carbohydrate; ConA: concavalin A; IFN-gamma, interferon gamma; LAK: lymphokine-activated killer; NK-natural killer; PHA - phytohemagglutinin

TNF-alpha, tumor necrosis factor-alpha; URT- Upper-respiratory-tract. 
Table 3 Carbohydrate supplementation studies included in the systematic review

\begin{tabular}{|c|c|c|c|}
\hline Study ID & Participants and exercise & Supplementation & Outcomes \\
\hline Nieman et al. (1997c) & $\begin{array}{l}30 \text { runners; } 2.5 \mathrm{~h} \text { of high-intensity } \\
\text { running (approximately } 75 \% \mathrm{VO}_{2} \\
\text { max) }\end{array}$ & $\begin{array}{l}0.75 \text { I of } 6 \% \mathrm{CHO} \text { before running } \\
\text { and then } 0.25 \mathrm{I} \text { of carbohydrate or } \\
\text { placebo fluid every } 15 \mathrm{~min} \text { during } \\
\text { exercise }\end{array}$ & Cell counts, NK activity, cortisol \\
\hline Nieman et al. (1997a) & $\begin{array}{l}30 \text { runners; } 2.5 \mathrm{~h} \text { of high-intensity } \\
\text { running (approximately } 75 \% \mathrm{VO}_{2} \\
\text { max) }\end{array}$ & $\begin{array}{l}0.75 \mathrm{I} \text { of } 6 \% \mathrm{CHO} \text { before running } \\
\text { and then } 0.25 \mathrm{I} \text { of carbohydrate } \\
\text { every } 15 \mathrm{~min} \text { during exercise }\end{array}$ & $\begin{array}{l}\text { Cortisol, cell counts, phagocytosis/ } \\
\text { oxidative burst }\end{array}$ \\
\hline $\begin{array}{l}\text { Nehlsen-Cannarella } \\
\text { et al. (1997) }\end{array}$ & $\begin{array}{l}30 \text { runners; } 2.5 \mathrm{~h} \text { of high-intensity } \\
\text { running (approximately } 75 \% \mathrm{VO}_{2} \\
\text { max) }\end{array}$ & $\begin{array}{l}0.75 \mathrm{I} \text { of } 6 \% \mathrm{CHO} \text { before running } \\
\text { and then } 0.25 \mathrm{I} \text { of carbohydrate } \\
\text { every } 15 \mathrm{~min}\end{array}$ & $\begin{array}{l}\text { Lymphocyte proliferative response } \\
\text { (ConA, PHA, PWM), IL-1ra; IL-6, } \\
\text { cortisol, NK cells }\end{array}$ \\
\hline
\end{tabular}

Henson et al. (1998)

Henson et al. (1999)

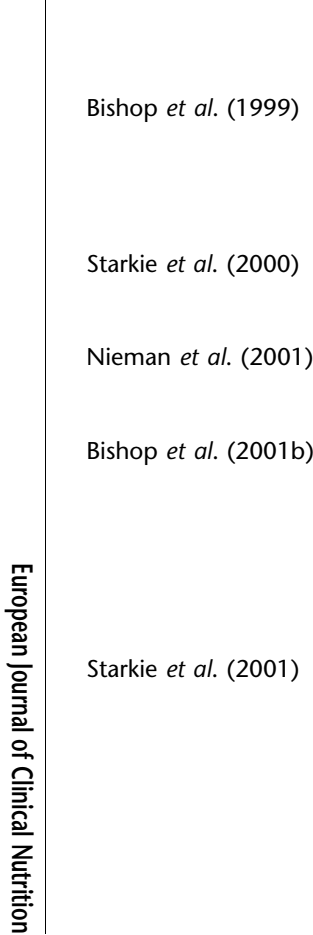

30 runners; $2.5 \mathrm{~h}$ of high-intensity running (approximately $75 \% \mathrm{VO}_{2}$ max)

10 triathletes; $2.5 \mathrm{~h}$ of running and cycling (approximately $75 \% \mathrm{VO}_{2}$ $\max )$

8 university team football players; 90 min specific exercise bouts ( 3 days apart)

6 endurance trained men; Cycling $2 \mathrm{~h}$ at $70 \%$ of peak $\mathrm{O}_{2}$ uptake

98 runners; Charlotte Marathon and Grandfather Mountain Marathon

12 male cyclists; cycling for $1 \mathrm{~h}$ at $60 \% \mathrm{~W}_{\text {max }}$ immediately followed by a time-trial ensuring an energy expenditure equivalent to cycling for $30 \mathrm{~min}$ at $80 \% \mathrm{~W}$. subjects repeated the protocol after 7 days

7 trained man; 60 min of exercise at a workload corresponding to each individual's lactate threshold on four randomised occasions (2 cycle ergometer, 2 treadmill)
0.75 I of $6 \% \mathrm{CHO}$ before running and then $0.25 \mathrm{I}$ of carbohydrate every 15 min during exercise

\section{6\% $\mathrm{CHO}$ beverage}

$\mathrm{CHO}(400 \mathrm{ml}$ lemon flavoured glucose solution $6 \% \mathrm{w} / \mathrm{v} 10 \mathrm{~min}$ before and $5 \mathrm{~min}$ after each $45 \mathrm{~min}$ of exercise

Total of $9 \mathrm{ml} / \mathrm{kg}$ of an $8 \% \mathrm{CHO}$

$1 \mathrm{l} / \mathrm{h}$ of a $6 \% \mathrm{CHO}$ beverage

administered during and for $1.5 \mathrm{~h}$ after marathon

Diet ensuring either greater than $70 \%(\mathrm{HICH})$ or less than $10 \%$

(LOW) of daily energy intake from

$\mathrm{CHO}$ for the 3 days before exercise

Total fluid intake of $12 \mathrm{ml}(\mathrm{kg} / \mathrm{BM})$ of a $6.4 \% \mathrm{CHO}$ solution during and after exercise
Results

Carbohydrate attenuated the increase in cortisol and increased glucose concentration and NK cell count.

No effect on NK activity

Carbohydrate increased glucose

concentrations, attenuated the increase in

cortisol, blood neutrophils and monocytes.

No effects on blood granulocyte/monocyte phagocytosis or oxidative burst activity

No effect on Con A-, PHA-, or PWM-induced lymphocyte proliferation

Smaller increase of IL- 6 and IL-1 ra immediately and $1.5 \mathrm{~h}$ post-run, respectively. Post-run plasma cortisol and IL-6 levels correlated positively with levels of IL-1 ra.

Significant effect on blood concentration of NK cells but no effect on NK cell activity

No effect on blood granulocyte and monocyte phagocytosis or oxidative burst activity Cortisol higher in the placebo group immediately post-run

Cortisol, lymphocyte proliferativ response (ConA, PHA, PWM)

Cortisol, lymphocyte proliferative response (ConA, PHA), IL-1 beta, NK cell activity

Cortisol, neutrophils, lymphocytes, LPS elastase release/neutrophyl, salivary $\lg A$

Monocyte LPS stimulated production of: IL-1 alpha-

TNF-alpha- and IL-6

Cortisol, plasma IL-10, IL-1ra, IL-6, IL-8

Cortisol/glucose, cell counts, plasma elastase and LPS elastase release/neutrophyl

Reduced lymphocytosis

Lower cortisol concentration

Reduced lymphocytosis

No effects on lymphocyte proliferative response or IL-1 beta

Reduced NK cell activity

No effect: cortisol, lymphocyte counts, salivary IgA and degranulation response of neutrophils to LPS.

Neutrophil counts $14 \%$ higher after the placebo trial than the carbohydrate trial No effect

Attenuated the increases in cortisol, IL-10 and IL-1ra

HIGH compared with the LOW trial was associated with higher plasma glucose concentration, lower plasma cortisol concentration, and lower circulating neutrophil count.

No differences for LPS-stimulated neutrophil degranulation per cell.

IL-6 gene expression in muscle biopsies, plasma IL-6 
Table 3 Continued

\begin{tabular}{|c|c|c|c|c|}
\hline Study ID & Participants and exercise & Supplementation & Outcomes & Results \\
\hline Koch et al. (2001) & $\begin{array}{l}10 \text { males; } 2 \text { sessions, } 14 \text { days apart, } \\
\text { high intensity exercise, short rest } \\
\text { interval squat workout }\end{array}$ & $\begin{array}{l}1.0 \mathrm{~g} / \mathrm{kg} \text { body mass } \mathrm{CHO} 10 \mathrm{~min} \\
\text { prior to and } 10 \mathrm{~min} \text { following } \\
\text { exercise }\end{array}$ & $\begin{array}{l}\text { Cortisol, leucocyte subsets, } \\
\text { lymphocyte proliferative response } \\
\text { (PHA) }\end{array}$ & $\begin{array}{l}\text { No effect on leukocyte subsets or cortisol } \\
\text { Lymphocyte proliferation was less depressed }\end{array}$ \\
\hline Bacurau et al. (2002) & $\begin{array}{l}12 \text { male athletes cycled for } 20 \mathrm{~min} \\
\text { at a velocity corresponding to } 90 \% \\
\text { of that obtained at the anaerobic } \\
\text { threshold and rested for } 20 \mathrm{~min} ; \\
\text { repeated six times }\end{array}$ & $\begin{array}{l}\text { CHO ( } 95 \% \text { glucose polymers and } \\
5 \% \text { fructose) at } 10 \%(\mathrm{w} / \mathrm{v}), 1 \mathrm{~g} / \mathrm{kg} / \\
\text { h every } 20 \mathrm{~min}, \text { starting at the } 10 \mathrm{th} \\
\text { minute of the first exercise period }\end{array}$ & $\begin{array}{l}\text { Cortisol, BMNC proliferative } \\
\text { response to PHA, cytokines (IL-1, } \\
\text { IL-2, TNF-alpha, IFN-gamma) }\end{array}$ & $\begin{array}{l}\text { All of the changes, except IFN gamma } \\
\text { production, were prevented by the ingestion } \\
\text { of } \mathrm{CHO}\end{array}$ \\
\hline Bishop et al. (2002) & $\begin{array}{l}6 \text { male soccer players; } 2 \text { exercise } \\
\text { trials, } 7 \text { days apart, on each } \\
\text { occasion, they completed } \\
6 \times 15 \text {-min periods of } \\
\text { intermittent running }\end{array}$ & $\begin{array}{l}\text { CHO beverages immediately } \\
\text { before and at } 15 \text {-min intervals } \\
\text { during the exercise }\end{array}$ & $\begin{array}{l}\text { Cortisol, glucose, plasma IL-6, } \\
\text { TNF-alpha, LPS elastase release/ } \\
\text { neutrophil }\end{array}$ & $\begin{array}{l}\text { Higher glucose, lower cortisol, IL-6, and fewe } \\
\text { neutrophils. } \\
\text { No effect on TNF-alpha } \\
\text { Less decrease in LPS-stimulated elastase release }\end{array}$ \\
\hline Scharhag et al. (2002) & $\begin{array}{l}14 \text { cyclists; cycling for } 4 \mathrm{~h} \text { in a } \\
\text { steady state at } 70 \% \text { of their } \\
\text { individual anaerobic threshold }\end{array}$ & 6 and $12 \% \mathrm{CHO}$ beverages & Neutrophil oxidative burst activity & $\begin{array}{l}\text { the decrease of the neutrophil oxidative burst } \\
\text { was attenuated }\end{array}$ \\
\hline Nieman et al. (2003) & $\begin{array}{l}16 \text { marathon runners; two sessions } \\
4-6 \text { weeks apart of } 3 \mathrm{~h} \text { treadmill at } \\
70 \% \text { maximal } \mathrm{O}_{2} \text { uptake }\end{array}$ & $\begin{array}{l}12 \mathrm{ml} / \mathrm{kg} \text { of } 6 \% \mathrm{CHO} 15-30 \mathrm{~min} \\
\text { before running and then over } 3 \mathrm{~h} \\
(4 \mathrm{ml} / \mathrm{kg}) \text { every } 15 \mathrm{~min}\end{array}$ & $\begin{array}{l}\text { Cortisol, cell counts, plasma IL-6, } \\
\text { IL-10, IL-1 ra, IL-8, salivary slgA, } \\
\text { gene expression of } 13 \text { cytokines in } \\
\text { muscle biopsies: IL-1a, IL-1b, IL-2, } \\
\text { IL-4, IL-5, IL-8, IL-10, IL-12p35, } \\
\text { IL-12p40, IFN-gama, IL-15, } \\
\text { TNF-alpha }\end{array}$ & $\begin{array}{l}\text { Plasma IL-6, IL-10, IL-1 ra, cortisol, but not IL-8, } \\
\text { were significantly lower } \\
\text { Attenuated the increase in mRNA for IL- } 6 \text { and } \\
\text { IL-8 }\end{array}$ \\
\hline McAnulty et al. (2003) & $\begin{array}{l}16 \text { marathon runners; two sessions } \\
4-6 \text { weeks apart of } 3 \mathrm{~h} \text { treadmill at } \\
70 \% \text { maximal } \mathrm{O}_{2} \text { uptake }\end{array}$ & $\begin{array}{l}12 \mathrm{ml} / \mathrm{kg} \text { of } 6 \% \mathrm{CHO} 15 \text { to } 30 \mathrm{~min} \\
\text { before running and then over } 3 \mathrm{~h} \\
(4 \mathrm{ml} / \mathrm{kg}) \text { every } 15 \mathrm{~min}\end{array}$ & $\begin{array}{l}\text { Cortisol, lipid peroxidation } \\
\text { (F2-isoprostanes and lipid } \\
\text { hydroperoxides, plasma } \\
\text { antioxidant potential) }\end{array}$ & $\begin{array}{l}\text { Attenuated the increase in cortisol } \\
\text { No effect on antioxidant potential and lipid } \\
\text { peroxidation }\end{array}$ \\
\hline Lancaster et al. (2003) & $\begin{array}{l}\text { Group A: } 8 \text { male cyclists; } 1 \text {-h of } \\
\text { high-intensity cycling } \\
\text { Group B: } 10 \text { cyclists; } 1 \text {-h of } \\
\text { high-intensity cycling }\end{array}$ & $\begin{array}{l}\text { Group } A: 75 \mathrm{~g} \mathrm{CHO} \text { as a glucose } \\
\text { solution at either } 15 \text { or } 75 \mathrm{~min} \\
\text { before exercise } \\
\text { Group B: } 25 \mathrm{~g} \text { or } 200 \mathrm{~g} \mathrm{CHO} \text { as a } \\
\text { glucose solution or a placebo } \\
45 \text { min before exercise }\end{array}$ & $\begin{array}{l}\text { Cortisol, BMNC proliferative } \\
\text { response to LPS, neutrophil/ } \\
\text { lymphocyte ratio, IL-6 }\end{array}$ & No effect \\
\hline Chan et al. (2003) & 9 males; resistance training bout & $\begin{array}{l}1 \mathrm{~g} / \mathrm{kg} \text { body mass } \mathrm{CHO} 10 \mathrm{~min} \\
\text { before and } 10 \mathrm{~min} \text { after exercise }\end{array}$ & $\begin{array}{l}\text { Cell counts, cortisol, glucose, } \\
\text { BMNC PHA stimulated production } \\
\text { of IL-2, IL-5 }\end{array}$ & $\begin{array}{l}\text { Attenuated the decrease of IL-2 and IL- } 5 \\
\text { Attenuated the increase in cortisol }\end{array}$ \\
\hline Bishop et al. (2003) & $\begin{array}{l}9 \text { trained cyclists; cycled for } 2 \mathrm{~h} \text { at } \\
75 \% \mathrm{VO}_{2} \text { max on two occasions }\end{array}$ & $\begin{array}{l}\text { CHO }(6.4 \%) \text { beverage ingestion } \\
\text { before }\left(5 \mathrm{ml} \times \mathrm{kg}^{-1}\right) \text {, during } \\
\left(2 \mathrm{ml} \times \mathrm{kg}^{-1}\right) \text {, and after } \\
\left(5 \mathrm{ml} \times \mathrm{kg}^{-1}\right) \text { the exercise }\end{array}$ & $\begin{array}{l}\text { Cortisol, cell counts, elastase LPS- } \\
\text { stimulated release/neutrophil, } \\
\text { elastase total neutrophil content }\end{array}$ & $\begin{array}{l}\text { Fewer numbers of circulating neutrophils } \\
\text { No effect on total neutrophil elastase content } \\
\text { LPS-stimulated neutrophil elastase release fell } \\
\text { post exercise by approximately } 47 \% \text { on the } \\
\text { PLA trial with no significant change from the } \\
\text { CHO trial }\end{array}$ \\
\hline Nieman et al. (2004) & $\begin{array}{l}30 \text { strength-trained subjects; lifting } \\
\text { weights for } 2 \mathrm{~h}(10 \text { exercises, } 4 \text { sets } \\
\text { each, } 10 \text { repetitions) }\end{array}$ & $\begin{array}{l}10 \mathrm{ml} \times \mathrm{kg}(-1) \times \mathrm{h}(-1) 6 \% \mathrm{CHO} \\
\text { beverage }\end{array}$ & $\begin{array}{l}\text { Cortisol, cell counts, plasma IL-6, } \\
\text { IL-10, IL-1 ra, IL-8, muscle glycogen } \\
\text { content and gene expression of IL- } \\
\text { 1alpha, IL-1 beta, IL-2, IL-4, IL-5, IL- } \\
\text { 6, IL-8, IL-10, IL-12p35, IL-12p40, } \\
\text { IL-15, IFN-gamma, TNF-alpha }\end{array}$ & No effect \\
\hline
\end{tabular}

Abbreviations: BM: body mass; BMNC- blood mononuclear cells; CHO, carbohydrate; ConA: concavalin A; LPS-lipopolysaccharide; PBL-peripheral blood lymphocytes; PHA - phytohemagglutinin; ; PUFA: polyunsaturated fatty acids; NK-natural killer; URT- Upper-respiratory-tract. 
Table 4 Vitamin supplementation studies included in the systematic review

\begin{tabular}{|c|c|c|c|c|}
\hline Study ID & Participants and exercise & Supplementation & Outcomes & Results \\
\hline Peters et al. (1993) & $\begin{array}{l}92 \text { runners; ' } 90 \mathrm{~km} \\
\text { Comrades Marathon' }\end{array}$ & $\begin{array}{l}600 \mathrm{mg} \text { vit. } \mathrm{C} \text { daily for } 21 \text { days } \\
\text { before race }\end{array}$ & URT infections & $\begin{array}{l}\text { Significantly more symptoms of URT } \\
\text { infection after the race in the placebo } \\
\text { group }\end{array}$ \\
\hline Peters et al. (1996) & $\begin{array}{l}178 \text { runners; ' } 90 \mathrm{~km} \\
\text { Comrades Marathon' }\end{array}$ & $\begin{array}{l}500 \mathrm{mg} \text { vit. } \mathrm{C}(\mathrm{C}, n=86), \\
500 \mathrm{mg} \text { vit. } \mathrm{C} \text { plus } 400 \mathrm{UI} \text { vit. } \mathrm{E} \\
(\mathrm{CE}, n=90), 300 \mathrm{mg} \text { vit. } \mathrm{C} \\
300 \mathrm{UI} \text { vit. } \mathrm{E} \text { plus } 18 \mathrm{mg} \text { beta- } \\
\text { carotene (CEB, } n=73 \text { ) daily for } \\
21 \text { days before race }\end{array}$ & URT infections & $\begin{array}{l}\text { Significantly more symptoms of URT } \\
\text { infection after the race in the placebo } \\
\text { group } \\
\text { vit. C alone as effective as combinations } \\
\text { with vit. E or beta-carotene in } \\
\text { preventing URT infections symptoms }\end{array}$ \\
\hline $\begin{array}{l}\text { Nieman et al. } \\
\text { (1997b) }\end{array}$ & $\begin{array}{l}30 \text { runners; } 2.5 \mathrm{~h} \text { of high- } \\
\text { intensity running }(75-80 \% \\
\text { maximal } \mathrm{O}_{2} \text { uptake) }\end{array}$ & $\begin{array}{l}\text { Vitamin } C(2 \times 500 \mathrm{mg} \text { tablets } \\
\text { daily) for } 8 \text { days before the race }\end{array}$ & $\begin{array}{l}\text { Cortisol, cell counts, NK cell } \\
\text { activity, lymphocyte proliferative } \\
\text { response, IL-6, phagocytosis, } \\
\text { oxidative burst }\end{array}$ & No effect \\
\hline $\begin{array}{l}\text { Himmelstein et al. } \\
\text { (1998) }\end{array}$ & $\begin{array}{l}44 \text { marathon runners; } 48 \\
\text { sedentary subjects }\end{array}$ & $\begin{array}{l}1000 \mathrm{mg} \text { vitamin } \mathrm{C} \text { daily for } 2 \\
\text { months prior and } 1 \text { month after } \\
\text { marathon }\end{array}$ & URT infections & No effect \\
\hline Singh et al. (1999) & $\begin{array}{l}10 \text { trained women runners; } \\
\text { treadmill run at } 65-70 \% \text { of } \\
\text { their } \mathrm{VO}_{2} \text { max. }\end{array}$ & $\begin{array}{l}\text { Zinc }(25 \mathrm{mg}) \text { or vitamin } \mathrm{E} \\
(400 \mathrm{IU}) \text { or placebo, twice a day, } \\
3 \text { days before and } 1 \text { day after }\end{array}$ & $\begin{array}{l}\text { Cortisol } \\
\text { IL-6 }\end{array}$ & No effect \\
\hline
\end{tabular}

29; Comrades $90 \mathrm{~km}$ marathon

\section{exercise}

$500 \mathrm{mg} /$ day vit C vs $1500 \mathrm{mg} /$ day vit $C$ vs placebo for 7 days before the race, on the day of

the race, and for 2 days

following completion

Petersen et al. (2001)

20 male recreational runners; $5 \%$ downhill $90-$ min treadmill run at $75 \% \mathrm{VO}_{2}$ $\max$

Peters et al. (2001a) 29; $90 \mathrm{~km}$ Comrades Marathon

Antioxidants $(500 \mathrm{mg}$ of vitamin $\mathrm{C}$ and $400 \mathrm{mg}$ of vitamin E) for 14 days before and 7 days after exercise

$500 \mathrm{mg} /$ day vit C vs $1500 \mathrm{mg}$ day vit $C$ vs placebo for 7 days before the race, on the day of the race, and for 2 days following completion

Peters et al. (2001b) 16; 90 km Comrades Marathon

Krause et al. (2001)

10 athletes; biathlon

Tauler et al. (2002)

20 duathlon athletes: runners and cyclists training 14 hours/week
Vitamin C $(2 \times 500 \mathrm{mg}$ tablets daily) for 7 days before the race, on the day of the race, and for 2 days following completion.

$2 \mathrm{~g}$ vitamin C daily for 1 week prior to biathlon

90 days supplementation with antioxidant mixture of vitamin $\mathrm{E}$ $(500 \mathrm{mg} /$ day $)$ and beta-carotene $(30 \mathrm{mg} /$ day) and in the last

15 days also with vitamin $C$

(1 g/day)
Cortisol, adrenaline, IL-10, IL1ra, TNF-alpha, IL-1 beta, IL-6, IL-8

Plasma vitamins, creatine kinase, lymphocytes, NK cell, cytokines (IL-1ra, IL-6).

Cortisol, adrenaline, IL-10,

IL-1Ra

Cortisol, cell counts, IL-6, TNFalpha, C-reactive protein

Neutrophil phagocytosis , neutrophil bactericidal ability Neutrophil glutathione peroxidase, glutathione reductase, superoxidedismutase and catalase activity
Serum cortisol significantly lower in the vit C1500 group than in combined $P$ and vit $C-500$ group

The increases in plasma IL-6, IL-10, IL-1 $\mathrm{ra}$, and IL-8 were attenuated in runners ingesting $1500 \mathrm{mg}$, but not $500 \mathrm{mg}$, vitamin $\mathrm{C}$ supplements No effect

Serum cortisol significantly lower in the VC-1500 group than in combined $\mathrm{P}$ and VC-500 group

The increases in plasma IL-10, IL-1 ra, and IL- 8 were attenuated in runners ingesting $1500 \mathrm{mg}$ but not $500 \mathrm{mg}$, vitamin C supplements

Significantly lower serum cortisol and C-reactive protein

No effect

Significantly higher glutathione versus glutathione disulfide ratio in neutrophils (about 20\%), enhanced antioxidant enzyme activity of superoxide dismutase and catalase in neutrophils 
Figure 1. Excluded and included study details are presented in Table 1 and Tables $2-5$, respectively.

\section{Description of included studies}

Overall, the quality of the reported trials was unsatisfactory. Using the Cochrane Collaboration approach for allocation concealment (2004), all included trials were allocated a grade $\mathrm{D}$, indicating that this score has not been assigned by the authors. None reported intention-to-treat analyses or randomisation methods. Compliance with the intervention and reasons for failure to comply were seldom described. None of the studies referred to intention-to-report adverse events related to the intervention. The quality rating score gave a median of 7 out of $14(\min =5, \max =11)$. In studies where subjects, method description and results were the same and exactly coincident, only one study was considered in the meta-analysis.

\section{Upper respiratory tract infections}

Three studies (Peters et al., 1993, 1996; Himmelstein et al., 1998), including 219 marathon runners, addressed the incidence of URT infections. In the study of Himmelstein et al. (1998), there were no significant differences in the incidence of URT infections after exercise when the subjects consumed $1000 \mathrm{mg}$ vitamin $\mathrm{C}$ daily for 2 months before and 1 month after the marathon. In this study, reasons for withdrawals were described as well as adherence to the protocol. The evaluation of URT infection symptoms was made using a semiquantitative list of respiratory symptoms. Two other studies assessed the impact of vitamin C supplementation, either alone or combined with vitamin $\mathrm{E}$ or beta-carotene, on the URT infection symptoms for 14 days after the race (Peters et al., 1993, 1996). In the study of Peters et al. (1993), the intervention group consumed $600 \mathrm{mg}$ of vitamin $C$ for 21 days prior to the ultra-marathon, and the URT infections were assessed for 14 days after the race. In this study, the number of runners of the placebo group reporting development of URT infection symptoms after the race was $68 \%$, which was significantly more than that reported by the vitamin C-supplemented group (33\%). In the study of Peters et al. (1996), athletes were supplemented with vitamin $\mathrm{C}$ alone $(500 \mathrm{mg} /$ day $)$ or combined with vitamin E (400 UI/day) or beta-carotene ( $18 \mathrm{mg} /$ day) during the 21 days before the race. Significantly more symptoms of URT infection in the placebo group were observed $(40.4 \%)$ compared with vitamin C (15.9\%) or combinations of vitamins $\mathrm{C}$ and $\mathrm{E}$ (25.5\%) or vitamins $\mathrm{C}, \mathrm{E}$ and beta-carotene (20.0\%). Vitamin C alone was as effective as when combined with vitamin $\mathrm{E}$ or beta-carotene in preventing URT infection symptoms. When the data from the studies was pooled, the rate ratio for URT infections after vitamin C supplementation against placebo was $0.49(0.34-0.71)$ (Figure 2). In two 
Table 5 Colostrum, plant sterols and polyunsaturated fatty acids supplementation studies included in the systematic review

\begin{tabular}{|c|c|c|c|c|}
\hline Study ID & Participants and exercise & Supplementation & Outcomes & Results \\
\hline Mero (1997) & $\begin{array}{l}9 \text { male sprinters/jumpers; } \\
\text { three strength and speed } \\
\text { training period of } 8 \text { days } \\
\text { separated by } 13 \text { days }\end{array}$ & $\begin{array}{l}125 \mathrm{ml} / \text { day bovine } \\
\text { colostrum supplement } \\
\text { containing IGF-I and lgG vs } \\
25-\mathrm{ml} / \text { day mixed with } \\
\text { placebo vs placebo }\end{array}$ & Saliva IgA, serum IGF-I, IgG & $\begin{array}{l}\text { Incresead serum IGF } \\
\text { No effects on } \lg A / \lg G\end{array}$ \\
\hline Bouic et al. (1999) & $\begin{array}{l}17 \text { marathon runners; ultra- } \\
\text { marathon in Cape Town, } \\
\text { South Africa }\end{array}$ & $\begin{array}{l}\text { Plant sterols and sterolins } \\
\text { (BSS:BSSG mixture }\end{array}$ & $\begin{array}{l}\text { Cortisol, lymphocytes } \\
\text { subsets, neutrophils, IL-6 }\end{array}$ & $\begin{array}{l}\text { Decreased IL-6 and cortisol } \\
\text { Attenuated neutrophilia, } \\
\text { lymphopenia and } \\
\text { leukocytosis } \\
\text { Increased CD } 3+\text { CD4 + }\end{array}$ \\
\hline Toft et al. (2000) & $\begin{array}{l}20 \text { male runners; The } \\
\text { Copenhagen Marathon, } \\
1998\end{array}$ & $\begin{array}{l}3.6 \mathrm{~g} \mathrm{n}-3 \text { PUFA plus } 21.6 \mathrm{mg} \\
\text { tocopherol for } 6 \text { weeks prior } \\
\text { to marathon }\end{array}$ & $\begin{array}{l}\text { Plasma TNF-alpha, IL-6, } \\
\text { TGF-beta, IL-1ra }\end{array}$ & No effect \\
\hline
\end{tabular}

Abbreviations: IGF-I: insulin-like growth factor I; NK-natural killer; PUFA: polyunsaturated fatty acids.

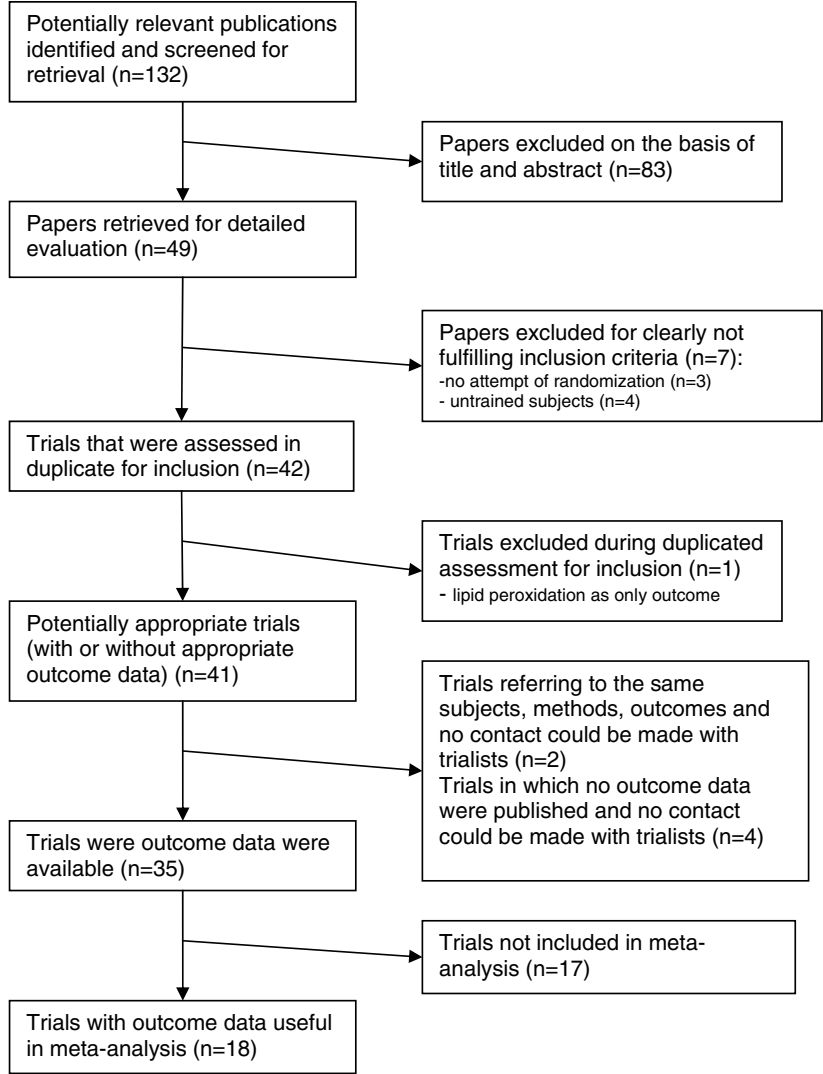

Figure 1 Systematic review flow chart summary.

additional studies, symptoms of infections after glutamine or branched-chain amino acids supplementation were assessed (Castell et al., 1996; Bassit et al., 2002). Questionnaire scores included infection symptoms other than respiratory, such as gastrointestinal complaints. Provision of glutamine or branched-chain amino acids containing drinks decreased the incidence of infection symptoms during the week that followed different types of exhaustive exercise (Castell et al., 1996; Bassit et al., 2002) compared to placebo.

\section{Cortisol}

In 24 of the included trials (Tables $2-5)(n=282)$, cortisol was one of the outcomes. CHO was the supplemented nutritional intervention in 15 of those trials. Cortisol data were only available in chart form, making data extraction for $\mathrm{CHO}$ intervention meta-analysis impossible in eight studies (Nehlsen-Cannarella et al., 1997; Nieman et al., 1997b, 2001, 2003; Bishop et al., 2001b, 2002; Bacurau et al., 2002; Lancaster et al., 2003). In all but one (Lancaster et al., 2003), the $\mathrm{CHO}$ intervention had a significant effect, decreasing post-exercise cortisol levels compared to placebo. Four of the eight trials included reported attenuated increase of cortisol after exercise for the treatment group $(n=96)$ compared with controls $(n=92)$ (Figure 3$)$. Subjects included in these trials were runners or cyclists, in contrast to the back squatters or weight lifters (Koch et al., 2001; Chan et al., 2003; Nieman et al., 2004) or football players (Bishop et al., 1999) in the studies where the CHO intervention had no significant effect on cortisol. The study by Lancaster et al. (2003), was the only one that examined the effect of $\mathrm{CHO}$ ingestion during the pre-exercise period on subsequent hormonal and immune responses to exercise. Statistical heterogeneity was excessive $\left(I^{2}=92.7 \%\right)$, and we were not able to identify a particular trial causing this excess variability. Pooling with such a high degree of heterogeneity is not advisable. However, had pooled data been used, the mean difference in serum cortisol after exercise between placebo and $\mathrm{CHO}$ intervention would have shown $-44.90 \mathrm{ng} \mathrm{ml}^{-1}(95 \% \mathrm{CI}$ : -78.12 to $-11.68 \mathrm{ng} \mathrm{ml}^{-1}$ ) (Figure 3). Four studies (Nieman et al., 2000b, 2002b; Peters et al., 2001a,b), all including ultramarathon runners, addressed the effect of vitamin $\mathrm{C}$ supplementation on cortisol. Two studies (Nieman et al., 2000b; Peters et al., 2001a) referred to the same subjects and 


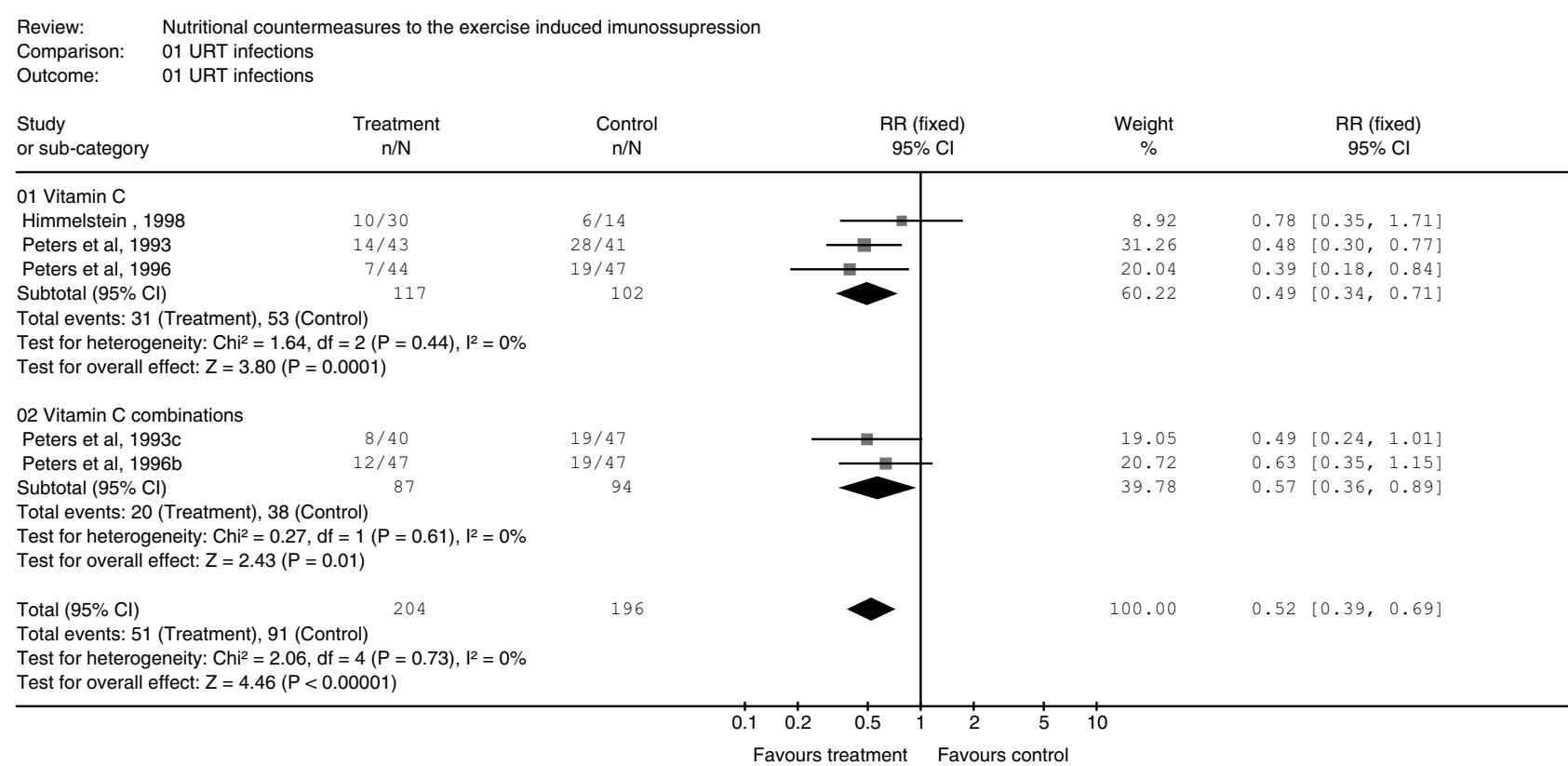

Figure 2 Effectiveness of nutritional interventions (vitamin C) compared with placebo on incidence of upper respiratory tract infections after exercise. Data are presented as relative risk for each study (boxes), $95 \% \mathrm{Cls}$ (horizontal lines) and summary as relative risk with $95 \% \mathrm{Cl}$ (diamonds).

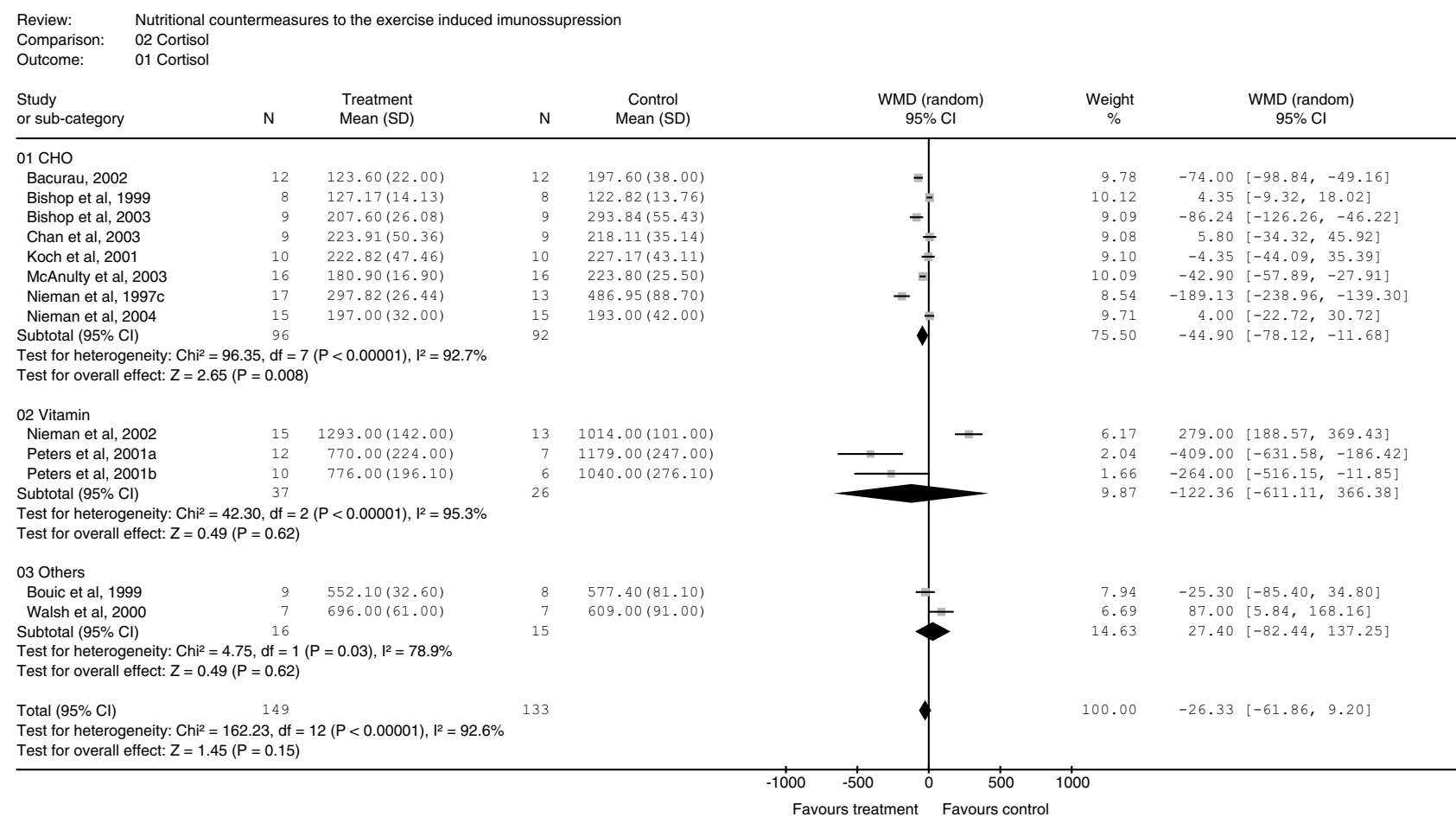

Figure 3 Effectiveness of nutritional interventions compared with placebo on serum cortisol levels after exercise. Data are presented as weighted mean differences for each study (boxes), $95 \% \mathrm{Cls}$ (horizontal lines) and summary weighted mean differences with $95 \% \mathrm{Cl}$ (diamonds).

only one was included. In the study of Peters et al. (2001a), vitamin $C$ had a significant effect on cortisol in ultramarathon runners when ingested in a dose greater than or equal to $1000 \mathrm{mg}$ /day for 7 days before race and 2 days after. In the study of Nieman et al. (2002b), $1500 \mathrm{mg}$ of vitamin C daily for the 7 days preceding the race had no effect on cortisol. 
The WMD on serum cortisol for vitamin C intervention against placebo was $-122.36 \mathrm{ng} \mathrm{ml}^{-1}$ (95\% CI -611.11 to $-366.38 \mathrm{ng} \mathrm{ml}^{-1}$ ) (Figure 3).

In two additional interventions, a mixture of plant sterols and sterolins attenuated the cortisol increase (Bouic et al., 1999) and a $1.2 \%$ glutamine drink had no effect compared with placebo (Walsh et al., 2000) in runners. An inhibitory effect of combined vitamin $\mathrm{C}$ and vitamin $\mathrm{E}$ supplementation (for 4 weeks) on plasma IL-6 and cortisol responses to prolonged exercise has been reported, although in physically active non-athletes (Fischer et al., 2004). Acute supplementation with zinc and vitamin $\mathrm{E}$ did not have an effect on the cortisol response to exercise in eumenorrheic runners (Singh et al., 1999).

\section{Cell counts}

When cell counts after exercise were available, those most immediately following exercise were chosen. Twenty-six trials were retrieved. Three (Nehlsen-Cannarella et al., 1997; Nieman et al., 1997c; Henson et al., 1998) were not included in the analysis because they referred to the same subjects as others (Nieman et al., 1997a; Scharhag et al., 2002). In another three studies (Bishop et al., 2002, 2003; Robson et al., 2003) data were only available in chart form, making data extraction impossible. Eighteen trials (Figures 4 and 5) (225 active plus 209 controls) reported counts of lymphocytes or neutrophils in a way that allowed data extraction. Glutamine supplementation had no significant effect on lymphocyte or neutrophil counts, while $\mathrm{CHO}$ had a mild effect on attenuation of the increase of neutrophils after exercise (WMD $=-1.45 ; 95 \% \mathrm{CI}-2.35$ to -0.54 ) (Figure 4 and 5 ) but no effect on lymphocytes (WMD $=-0.21 ; 95 \%$ CI -0.44 to 0.01 ). Although vitamin C significantly increased lymphocyte counts after exercise $(\mathrm{WMD}=0.30$; 95\% CI 0.00-0.61), it did not have an effect on neutrophils (Figure 5) (WMD $=0.05 ; 95 \% \mathrm{CI}-1.09$ to 1.19$)$ compared to placebo.

\section{Plasma cytokines}

In twenty-three of the included studies (Tables 2-5), cytokines or chemokines was one of the outcomes. There was no tendency towards a predominant effect on the part of

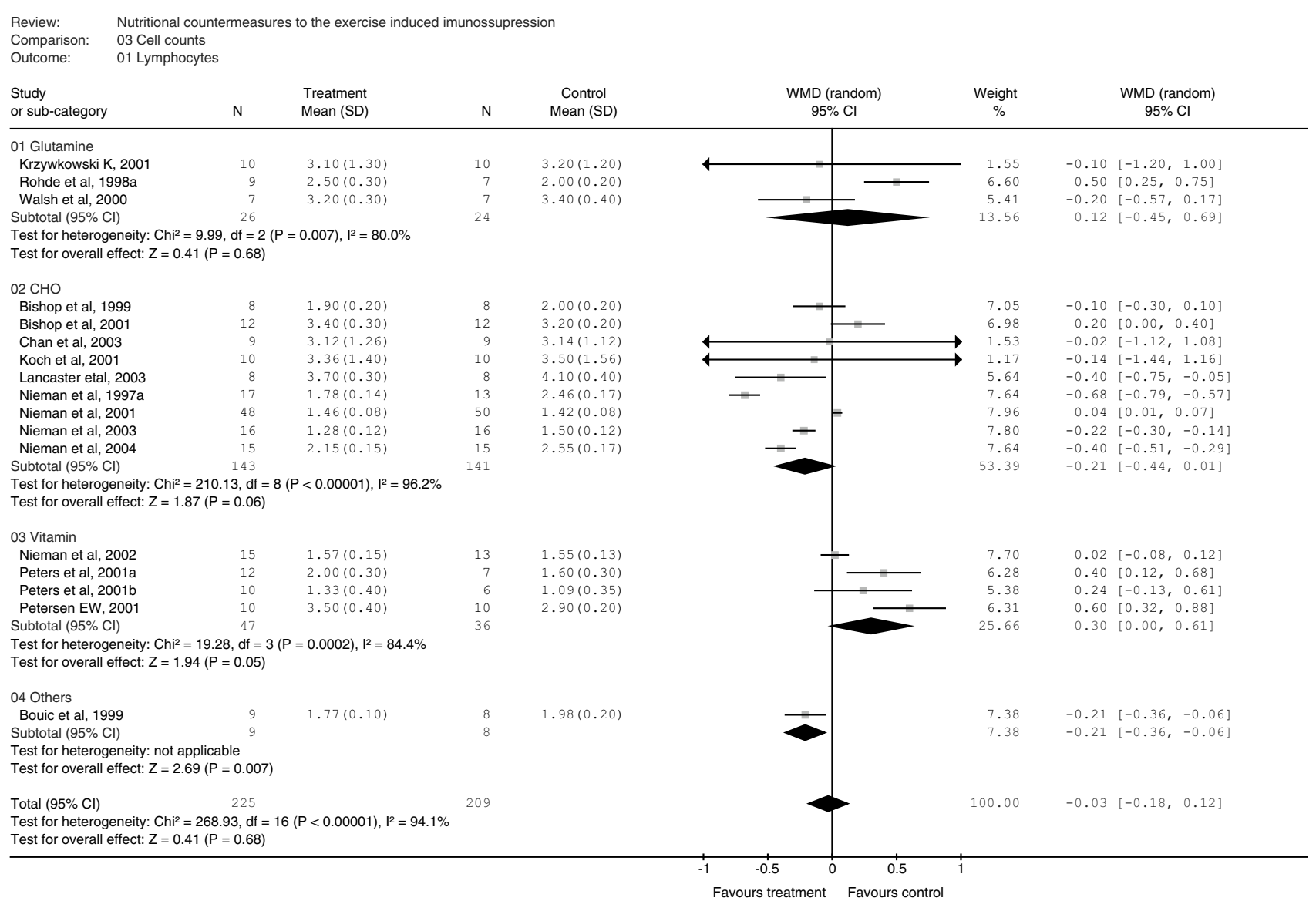

Figure 4 Effectiveness of nutritional interventions compared with placebo on lymphocytes counts $\left(10^{9} \mathrm{I}^{-1}\right)$ after exercise. Data are presented as weighted mean differences for each study (boxes), $95 \% \mathrm{Cls}$ (horizontal lines) and summary weighted mean differences with $95 \% \mathrm{Cl}$ (diamonds). 


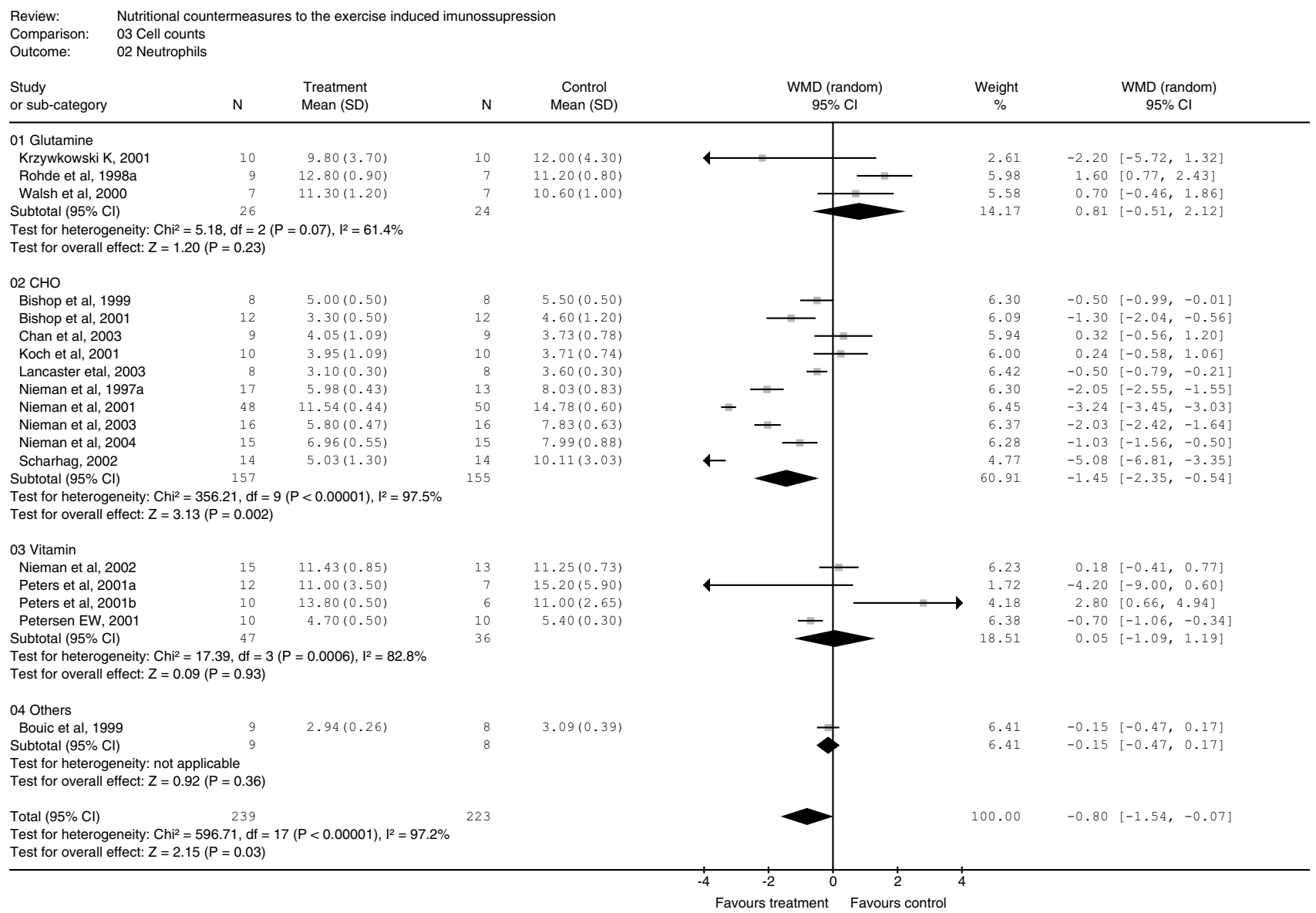

Figure 5 Effectiveness of nutritional interventions compared with placebo on neutrophils counts $\left(10^{9} \mathrm{~L}^{-1}\right)$ after exercise. Data are presented as weighted mean differences for each study (boxes), 95\% Cls (horizontal lines) and summary weighted mean differences with $95 \% \mathrm{Cl}$ (diamonds).

any nutritional supplement. Carbohydrate intake before or during exercise had a major effect in attenuating increases in IL-6, IL-10, IL-2, IL-8 or IL-1ra in six studies (NehlsenCannarella et al., 1997; Nieman et al., 2001, 2003; Starkie et al., 2001; Bacurau et al., 2002; Bishop et al., 2002) but failed to show any significant effect in nine studies (Henson et al., 1999; Starkie et al., 2000; Petersen et al., 2001; Nieman et al., 2001, 2003, 2004; Bishop et al., 2002; Lancaster et al., 2003; Chan et al., 2003). Vitamin C intake had inconsistent effects on plasma increases of IL-6, IL-10, IL-1ra and IL-8. Doses of $1500 \mathrm{mg}$ of vitamin $\mathrm{C}$ daily were reported to attenuate the increase in these cytokines after exercise (Nieman et al., 2000b; Peters et al., 2001a) or have no effect (Nieman et al., 2002b) at lower doses of 1000 or $500 \mathrm{mg}$ daily (Nieman et al., 1997b; Peters et al., 2001b). Of the two studies where glutamine was given as a supplement, one study showed glutamine to augment the increase of plasma IL-6 (Hiscock et al., 2003) after exercise, while the other (Castell et al., 1997) did not. Polyunsaturated fatty acids had no effect on plasma TNF-alfa, IL-6, TGF-beta and IL-1ra (Toft et al., 2000). The plant sterols and sterolins B-sitosterol (BSS) and B-sitosterol glucoside (BSSG) mixture attenuated the increase of IL-6 after exercise (Bouic et al., 1999).

\section{NK cell cytolytic activity, neutrophil oxidative burst, phagocytosis and salivary immunoglobulin A ( $\lg \mathrm{A})$}

Five studies (Nieman et al., 1997b, c; Rohde et al., 1998; Henson et al., 1999; Krzywkowski et al., 2001a) assessed NKCA, expressing it in lytic units or adjusting for NK cell counts. NKCA was affected by the intervention in one study (Henson et al., 1999), where triathletes consumed a 6\% CHO beverage. The interventions in the other four studies had no effect on NKCA. Two trials showed increased neutrophil oxidative burst activity after a 3-week supplementation period with multivitamin-minerals, including beta-carotene and vitamins $\mathrm{C}$ and $\mathrm{E}$ (Scharhag et al., 2002) and a $12 \% \mathrm{CHO}$ beverage (Robson et al., 2003), but this was not observed in the other four studies where vitamin C (Nieman et al., 1997b; Krause et al., 2001), glutamine (Walsh et al., 2000) or $\mathrm{CHO}$ (Nieman et al., 1997a) were used. Lipopolysaccharide- 
stimulated neutrophil elastase release was investigated in five trials (Bishop et al., 1999, 2001b, 2002, 2003; Walsh et al., 2000), but only in one (Bishop et al., 2002), in which $\mathrm{CHO}$ was ingested before and during the exercise, was there an attenuation of the decrease in the elastase release per neutrophil. From the seven trials (Nehlsen-Cannarella et al., 1997; Henson et al., 1998, 1999; Rohde et al., 1998; Koch et al., 2001; Krzywkowski et al., 2001a) that assessed the lymphocyte proliferative response, only one (Koch et al., 2001) found a less depressed proliferative response when $\mathrm{CHO}$ was used. None of the interventions had any effect on salivary IgA in the five trials in which IgA was one of the outcomes (Mero, 1997; Bishop et al., 1999; Krzywkowski et al., 2001b; Nieman et al., 2003; Palmer et al., 2003).

\section{Reviewers' conclusions}

\section{Limitations of the studies}

The methodological quality of most of the included trials was poor. The low median score for the quality rating is not surprising considering that the two major classified items, randomisation and blinding, were not reported. Low-quality trials, particularly those not reporting allocation concealment and those not reporting blinding, are known to favour interventions (Moher et al., 1998; Sterne et al., 2001). The highest scores found were the result of summing individual items. The use of such scores, however, could be arguable (Juni et al., 1999), reflecting the difficulties in determining fair quality rates. Evaluating the suppression of one immunological parameter at a time runs the risk of disregarding changes in host resistance as a whole. This reductionist approach, taken in most of the studies conducted, fails to bring to light the impact of the interventions on overall host resistance. A decreased NKCA function does not necessarily mean an increased susceptibility to infection if, for instance, it is counterbalanced by an increased number of neutrophils (Keil et al., 2001). A validated mathematical model (Keil et al., 1999) should be used to estimate and predict the relationship between multiple immunological parameters and host resistance. In addition, clinical end points, such as incidence of infections, should be used.

\section{Discussion}

\section{Glutamine}

The plasma concentration of the 'conditionally essential' amino acid glutamine, the most abundant in the human body, is lowered by stress or strenuous physical activity. This is most likely due to increased cellular needs that exceed the supply available from diet or muscle. The plasma glutamine response to exercise is biphasic. It is characterised by an increased concentration during short-term exercise, followed by a decrease after more prolonged exercise (Rennie et al., 1981; Castell and Newsholme, 1998). This and knowledge about glutamine effects on in vitro immunity responses led to the 'glutamine hypothesis' as one explanation of immunodepression after exercise (Newsholme and Parry-Billings, 1990). It has been postulated that restoring glutamine levels after prolonged exercise to physiological levels may help the immune system to resist infections. Although oral provision of glutamine, or branched chain amino acids as a glutamine precursor, abolishes the post-exercise plasma glutamine decrease, it has no consistent effect on lymphocyte or neutrophil counts (Rohde et al., 1998; Walsh et al., 2000; Peters et al., 2001a; Krzywkowski et al., 2001a), salivary IgA (Krzywkowski et al., 2001b), oxidative burst activity (Walsh et al., 2000), NKCA (Rohde et al., 1998; Walsh et al., 2000) or plasma IL-6 (Castell et al., 1997; Hiscock et al., 2003) after exercise. Although it was suggested that glutamine could enhance Th1-type immune response (Bassit et al., 2002) in swimmers submitted to 4 weeks of intensive training, there was no significant difference in glutamine levels between athletes who developed URT infection and those who did not (Mackinnon and Hooper, 1996). In two studies (Castell et al., 1996; Bassit et al., 2002), infection symptoms after prolonged strenuous exercise in athletes supplemented with glutamine was significantly lower than in the placebo group. The study of Castell et al. (1996) included data from eight separate studies. Both studies included symptoms questionnaires assessing not only URT symptoms but also others such as vomiting or diarrhoea. The available data do not provide evidence to support the glutamine hypothesis.

\section{Carbohydrate}

It has been speculated that athletes exercising in a low $\mathrm{CHO}$ status are placing themselves at an increased risk of exerciseinduced immunodepression. Cells of the immune system have high metabolic rates and $\mathrm{CHO}$ availability can theoretically influence the immune response to exercise and the ability to maintain immunocompetence. Subjects performing exercise on diets for several days with less than $10 \%$ of energy intake from $\mathrm{CHO}$ have larger stress hormone (cortisol, adrenaline) and plasma cytokine (IL1ra, IL6, IL10) responses than those on normal or high CHO diets (Mitchell et al., 1998; Bishop et al., 2001c). There are no trials addressing the efficacy of $\mathrm{CHO}$ supplementation on preventing URT infections. Attenuation of serum cortisol increases, both in runners and cyclists (Nieman et al., 1997c, 2003, 2004; Bishop et al., 1999, 2003; Koch et al., 2001; Bacurau et al., 2002; McAnulty et al., 2003; Chan et al., 2003) does take place after supplementation (about $1 \mathrm{l} / \mathrm{h}$ of a $6 \%$ carbohydrate beverage), but whether this reduces URT infections remains to be proven. There is no evidence supporting effects of $\mathrm{CHO}$ supplementation on lymphocyte counts, cytokines or salivary IgA after exercise (Table 3, Figures 4 and 5).

\section{Antioxidants and vitamins}

Exercise can produce an imbalance between the free radicals and reactive oxygen species (ROS) produced and the 
antioxidant defence system. The antioxidant defence mechanism prevents the generation of ROS or intercepts any that is formed. The dose-response between vitamin intake and immune stimulatory effect is not linear. In fact, megadoses of vitamins may even impair immune function in athletes (Prasad, 1980). Although the cellular antioxidant mechanism adapts efficiently to acute and chronic exercise (Mena et al., 1991), extreme physical exercise causes oxidative damage to athletes, which is reflected by increases in plasma levels of malondialdehyde (Marzatico et al., 1997), urine 8hydroxideoxyguanosine (Radak et al., 2000) and erythrocyte catalase activity (Tauler et al., 1999), which could relate to exercise-induced immunodepression. Vitamin C supplementation augmented the increase in lymphocyte counts after exercise (Petersen et al., 2001; Peters et al., 2001b), attenuated the serum cortisol increase in ultramarathon runners (Peters et al., 2001a,b; Nieman et al., 2002b) and attenuated the increases in inflammatory cytokines (Nieman et al., 1997b, 2000b; Peters et al., 2001a, b), when ingested in doses greater than or equal to $1000 \mathrm{mg} /$ day, but not on $500 \mathrm{mg} /$ day. However, the risks of vitamin $\mathrm{C}$ excessive intake may outweigh any potential benefits, and none of the trials assessed adverse events. High-dose vitamin $\mathrm{C}$ intake can cause DNA damage, suggesting a possible link to increased cancer susceptibility (Gerster, 1999). Vitamin C intake in excess of $1000 \mathrm{mg} /$ day has been associated with kidney oxalate stone formation (Baxmann et al., 2003), impaired absorption of copper and excessive absorption of iron (Gerster, 1999). The phagocytic ability of neutrophils is one of the most important host defences against infections. Its antimicrobial mechanisms are activated when neutrophils undergo the oxidative burst and produce more ROS. The natural antioxidant systems that protect neutrophils could be depleted after intensive exercise, and the oxidative burst cannot then be carried out in an effective way. The supplementation with vitamin $\mathrm{C}$ or beta-carotene plus vitamin $\mathrm{C}$ and $\mathrm{E}$ failed, however, to show consistent results in improving oxidative burst activity (Nieman et al., 1997b; Krause et al., 2001; Robson et al., 2003).

\section{Other interventions}

Interventions where only one trial was available included n-3 polyunsaturated fatty acids (Toft et al., 2000) (no effects), a plant sterols mixture (Bouic et al., 1999) (which decreased IL-6 and cortisol and attenuated both the increase in neutrophil and the decrease in lymphocyte counts) and bovine colostrum (Mero, 1997) (no effect).

If the excluded papers were considered for the analysis, the reported results would not be different for the $\mathrm{CHO}$ interventions.

\section{Limitations and strengths of the review}

In common with all meta-analyses, this systematic review may have included studies in which the interventions and characteristics of the human subjects were too dissimilar for comparison, resulting in questionable conclusions on the supplementation used. The athletes included were from different sports and exercised in different environmental and stress conditions (e.g. during winter or summer); this makes any generalisations open to question. Another problem was the wide range of reported outcome measures. Exerciseinduced immunodepression is multifactorial, depending on mechanisms related to neuro-immune-endocrine systems. We tried to compose clinically useful and comparable outcome categories from the trials. Measurements for the number of neutrophils or lymphocytes and NKCA in the blood does not, however, reflect the performance of the immune system as a whole. The immune system has many overlapping components, sometimes with shared redundant functions. Although the change of one or more immune functions may affect the host ability to resist infections, it is not possible to predict the overall effects of small to moderate changes in immune parameters on host resistance. The most useful outcome from a clinical point of view, the incidence of URT infections, was only used in two of the included studies. In these, diagnosis was based on URT symptoms assessed by questionnaire or telephone interview.

The present study has important strengths. Because of a comprehensive search strategy, omission of important trials seems unlikely. To increase reliability we used two independent reviewers for study selection. We provided both a comprehensive summary of controlled trials and a quantitative estimate of the relative importance of specific nutritional countermeasures, such as $\mathrm{CHO}$, glutamine and vitamins, with respect to specific immune parameters.

\section{Implications for practice and future research}

Besides improving methodological issues, such as randomisation procedures, allocation concealment, selection of athletes, and reporting of adverse events, future studies should make an effort to consider the immune system as a whole (Gleeson, 2005). Trials should also refer to the exercise training strategy as exercise itself is an important immunomodulator (Espersen et al., 1996). Questions to be addressed include: (i) Are the athletes who show more 'immunodepression' more prone to URT infections during the weeks following exercise? (ii) Which are the relevant outcomes to assess exercise-induced immunodepression? (iii) Is a decrease in nonspecific immunity after intense exercise a normal protective response, with mild immunodepression being an attempt to limit inflammation? (iv) When should this be considered pathological?

Although the prevention of URT infections by vitamin C was supported by two trials, further studies are needed to provide unequivocal proof of effect. Consumption of carbohydrate beverages during exercise appears to attenuate some of the immunodepressive effects of prolonged exercise, but confirmation of any clinical significance in this awaits further 
research. There is no evidence to support a role for any other nutritional supplements in preventing exercise-induced immunodepression or in protecting against infections.

\section{Acknowledgements}

We thank the authors of the trials included in this review who provided supplementary data in response to our correspondence (Castell et al., 1996; Bassit et al., 2000; Koch et al., 2001; Krzywkowski et al., 2001a; Chan et al., 2003). We thank the following $\mathrm{Ga}^{2}$ len members and participants in the 'Sports, Allergy and Asthma' Work Package for reviewing the manuscript: Kai-Hakon Carlsen, Sergio Bonini, Todor Popov, Stefano Del Giacco. We thank Luís Azevedo for reviewing the statistical analysis. We thank the reviewers who contributed their valuable time and expertise toward development of this manuscript. André Moreira holds a Grant from the Finnish Centre for International Mobility and a Fellowship Award from the European Academy of Allergy and Clinical Immunology.

\section{References}

Bacurau RF, Bassit RA, Sawada L, Navarro F, Martins Jr E, Costa Rosa LF (2002). Carbohydrate supplementation during intense exercise and the immune response of cyclists. Clin Nutr 21, 423-429.

Bassit RA, Sawada LA, Bacurau RF, Navarro F, Costa Rosa LF (2000). The effect of BCAA supplementation upon the immune response of triathletes. Med Sci Sports Exerc 32, 1214-1219.

Bassit RA, Sawada LA, Bacurau RF, Navarro F, Martins Jr E, Santos RV et al. (2002). Branched-chain amino acid supplementation and the immune response of long-distance athletes. Nutrition 18, 376-379.

Baxmann AC, De OGM, Heilberg IP (2003). Effect of vitamin C supplements on urinary oxalate and $\mathrm{pH}$ in calcium stone-forming patients. Kidney Int 63, 1066-1071.

Bishop NC, Blannin AK, Robson PJ, Walsh NP, Gleeson M (1999). The effects of carbohydrate supplementation on immune responses to a soccer-specific exercise protocol. J Sports Sci 17, 787-796.

Bishop NC, Blannin AK, Walsh NP, Gleeson M (2001a). Carbohydrate beverage ingestion and neutrophil degranulation responses following cycling to fatigue at $75 \% \mathrm{VO}_{2}$ max. Int I Sports Med 22, 226231.

Bishop NC, Gleeson M, Nicholas CW, Ali A (2002). Influence of carbohydrate supplementation on plasma cytokine and neutrophil degranulation responses to high intensity intermittent exercise. Int J Sport Nutr Exerc Metab 12, 145-156.

Bishop NC, Walsh NP, Scanlon GA (2003). Effect of prolonged exercise and carbohydrate on total neutrophil elastase content. Med Sci Sports Exerc 35, 1326-1332.

Bishop NC, Walsh NP, Haines DL, Richards EE, Gleeson M (2001b). Pre-exercise carbohydrate status and immune responses to prolonged cycling: I. Effect on neutrophil degranulation. Int J Sport Nutr Exerc Metab 11, 490-502.

Bishop NC, Walsh NP, Haines DL, Richards EE, Gleeson M (2001c). Pre-exercise carbohydrate status and immune responses to prolonged cycling: II. Effect on plasma cytokine concentration. Int J Sport Nutr Exerc Metab 11, 503-512.

Bouic PJ, Clark A, Lamprecht J, Freestone M, Pool EJ, Liebenberg RW et al. (1999). The effects of B-sitosterol (BSS) and B-sitosterol glucoside (BSSG) mixture on selected immune parameters of marathon runners: inhibition of post marathon immune suppression and inflammation. Int J Sports Med 20, 258-262.
Castell LM, Newsholme EA (1998). Glutamine and the effects of exhaustive exercise upon the immune response. Can J Physiol Pharmacol 76, 524-532.

Castell LM, Poortmans JR, Newsholme EA (1996). Does glutamine have a role in reducing infections in athletes? Eur J Appl Physiol Occup Physiol 73, 488-490.

Castell LM, Poortmans JR, Leclercq R, Brasseur M, Duchateau J, Newsholme EA (1997). Some aspects of the acute phase response after a marathon race, and the effects of glutamine supplementation. Eur J Appl Physiol Occup Physiol 75, 47-53.

Chan MA, Koch AJ, Benedict SH, Potteiger JA (2003). Influence of carbohydrate ingestion on cytokine responses following acute resistance exercise. Int J Sport Nutr Exerc Metab 13, 454-465.

Contor L (2001). Functional Food Science in Europe. Nutr Metab Cardiovasc Dis 11, 20-23.

DerSimonian R, Laird N (1986). Meta-analysis in clinical trials. Control Clin Trials 7, 177-188.

Espersen GT, Elbaek A, Schmidt-Olsen S, Ejlersen E, Varming K, Grunnet N (1996). Short-term changes in the immune system of elite swimmers under competition conditions. Different immunomodulation induced by various types of sport. Scand J Med Sci Sports 6, 156-163.

Fischer CP, Hiscock NJ, Penkowa M, Basu S, Vessby B, Kallner A et al. (2004). Supplementation with vitamins C and E inhibits the release of interleukin-6 from contracting human skeletal muscle. J Physiol 558, 633-645.

Gerster H (1999). High-dose vitamin C: a risk for persons with high iron stores? Int I Vitam Nutr Res 69, 67-82.

Gleeson M (2005). Assessing immune function changes in exercise and diet intervention studies. Curr Opin Clin Nutr Metab Care 8, 511-515.

Gleeson M, Blannin AK, Walsh NP, Bishop NC, Clark AM (1998). Effect of low- and high-carbohydrate diets on the plasma glutamine and circulating leukocyte responses to exercise. Int $J$ Sport Nutr 8, 49-59.

Gleeson M, Lancaster GI, Bishop NC (2001). Nutritional strategies to minimise exercise-induced immunosuppression in athletes. Can J Appl Physiol 26 (Suppl), S23-S35.

Gleeson M, Nieman DC, Pedersen BK (2004). Exercise, nutrition and immune function. J Sports Sci 22, 115-125.

Grimble RF (2001). Nutritional modulation of immune function. Proc Nutr Soc 60, 389-397.

Henson DA, Nieman DC, Blodgett AD, Butterworth DE, Utter A, Davis JM et al. (1999). Influence of exercise mode and carbohydrate on the immune response to prolonged exercise. Int $J$ Sport Nutr 9, 213-228.

Henson DA, Nieman DC, Parker JC, Rainwater MK, Butterworth DE, Warren BJ et al. (1998). Carbohydrate supplementation and the lymphocyte proliferative response to long endurance running. Int J Sports Med 19, 574-580.

Himmelstein S, Robergs R, Koehler K, Lewis S, Qualls C (1998). Vitamin C supplementation and upper respiratory tract infections in marathon runners. J Exerc Physiol (online) 1, 1-17.

Hiscock N, Petersen EW, Krzywkowski K, Boza J, Halkjaer-Kristensen J, Pedersen BK (2003). Glutamine supplementation further enhances exercise-induced plasma IL-6. J Appl Physiol 95, 145-148.

Juni P, Witschi A, Bloch R, Egger M (1999). The hazards of scoring the quality of clinical trials for meta-analysis. JAMA 282, 1054-1060.

Keil D, Luebke RW, Pruett SB (2001). Quantifying the relationship between multiple immunological parameters and host resistance: probing the limits of reductionism. J Immunol 167, 4543-4552.

Keil D, Luebke RW, Ensley M, Gerard PD, Pruett SB (1999). Evaluation of multivariate statistical methods for analysis and modeling of immunotoxicology data. Toxicol Sci 51, 245-258.

Koch AJ, Potteiger JA, Chan MA, Benedict SH, Frey BB (2001). Minimal influence of carbohydrate ingestion on the immune response following acute resistance exercise. Int I Sport Nutr Exerc Metab 11, 149-161. 
Krause R, Patruta S, Daxbock F, Fladerer P, Biegelmayer C, Wenisch C (2001). Effect of vitamin C on neutrophil function after highintensity exercise. Eur J Clin Invest 31, 258-263.

Krzywkowski K, Petersen EW, Ostrowski K, Kristensen JH, Boza J, Pedersen BK (2001a). Effect of glutamine supplementation on exercise-induced changes in lymphocyte function. Am J Physiol Cell Physiol 281, C1259-C1265.

Krzywkowski K, Petersen EW, Ostrowski K, Link-Amster H, Boza J, Halkjaer-Kristensen J, Pedersen BK (2001b). Effect of glutamine and protein supplementation on exercise-induced decreases in salivary IgA. J Appl Physiol 91, 832-838.

Lancaster GI, Jentjens RL, Moseley L, Jeukendrup AE, Gleeson M (2003). Effect of pre-exercise carbohydrate ingestion on plasma cytokine, stress hormone, and neutrophil degranulation responses to continuous, high-intensity exercise. Int J Sport Nutr Exerc Metab 13, 436-453.

Mackinnon LT, Hooper SL (1996). Plasma glutamine and upper respiratory tract infection during intensified training in swimmers. Med Sci Sports Exerc 28, 285-290.

Marzatico F, Pansarasa O, Bertorelli L, Somenzini L, Della VG (1997). Blood free radical antioxidant enzymes and lipid peroxides following long-distance and lactacidemic performances in highly trained aerobic and sprint athletes. I Sports Med Phys Fitness 37, 235-239.

McAnulty SR, McAnulty LS, Nieman DC, Morrow JD, Utter AC, Henson DA et al. (2003). Influence of carbohydrate ingestion on oxidative stress and plasma antioxidant potential following a $3 \mathrm{~h}$ run. Free Radical Res 37, 835-840.

Mena P, Maynar M, Gutierrez JM, Maynar J, Timon J, Campillo JE (1991). Erythrocyte free radical scavenger enzymes in bicycle professional racers. Adaptation to training. Int J Sports Med 12, 563-566.

Mero A (1997). Effects of bovine colostrum supplementation on serum IGF-I, IgG, hormone, and saliva IgA during training. $J$ of Appl Physiol Respir, Environ Exerc physiology 83, 1144-1151.

Mitchell JB, Pizza FX, Paquet A, Davis BJ, Forrest MB, Braun WA (1998). Influence of carbohydrate status on immune responses before and after endurance exercise. J Appl Physiol 84, 1917-1925.

Moher D, Pham B, Jones A, Cook DJ, Jadad AR, Moher M et al. (1998). Does quality of reports of randomised trials affect estimates of intervention efficacy reported in meta-analyses? Lancet 352, 609613.

Nehlsen-Cannarella SL, Fagoaga OR, Nieman DC, Henson DA, Butterworth DE, Schmitt RL et al. (1997). Carbohydrate and the cytokine response to $2.5 \mathrm{~h}$ of running. J Appl Physiol 82, 16621667.

Newsholme EA, Parry-Billings M (1990). Properties of glutamine release from muscle and its importance for the immune system. JPEN J Parenter Enteral Nutr 14, 63S-67S.

Nieman DC (1994). Exercise, upper respiratory tract infection, and the immune system. Med Sci Sports Exerc 26, 128-139.

Nieman DC (1997). Immune response to heavy exertion. I Appl Physiol 82, 1385-1394.

Nieman DC, Davis JM, Brown VA, Henson DA, Dumke CL, Utter AC et al. (2004). Influence of carbohydrate ingestion on immune changes after $2 \mathrm{~h}$ of intensive resistance training. J Appl Physiol 96, 1292-1298.

Nieman DC, Davis JM, Henson DA, Walberg-Rankin J, Shute M, Dumke CL et al. (2003). Carbohydrate ingestion influences skeletal muscle cytokine mRNA and plasma cytokine levels after a 3-h run. J Appl Physiol 94, 1917-1925.

Nieman DC, Fagoaga OR, Butterworth DE, Warren BJ, Utter A, Davis JM et al. (1997a). Carbohydrate supplementation affects blood granulocyte and monocyte trafficking but not function after $2.5 \mathrm{~h}$ or running. Am J Clin Nutr 66, 153-159.

Nieman DC, Henson DA, Butterworth DE, Warren BJ, Davis JM, Fagoaga OR et al. (1997b). Vitamin C supplementation does not alter the immune response to 2.5 hours of running. Int J Sport Nutr 7, 173-184.
Nieman DC, Henson DA, Fagoaga OR, Utter AC, Vinci DM, Davis JM et al. (2002a). Change in salivary IgA following a competitive marathon race. Int J Sports Med 23, 69-75.

Nieman DC, Henson DA, Garner EB, Butterworth DE, Warren BJ, Utter A et al. (1997c). Carbohydrate affects natural killer cell redistribution but not activity after running. Med Sci Sports Exerc $29,1318-1324$.

Nieman DC, Henson DA, Gusewitch G, Warren BJ, Dotson RC, Butterworth DE et al. (1993). Physical activity and immune function in elderly women. Med Sci Sports Exerc 25, 823-831.

Nieman DC, Henson DA, McAnulty SR, McAnulty L, Swick NS, Utter $\mathrm{AC}$ et al. (2002b). Influence of vitamin $\mathrm{C}$ supplementation on oxidative and immune changes after an ultramarathon. $J$ Appl Physiol 92, 1970-1977.

Nieman DC, Henson DA, Smith LL, Utter AC, Vinci DM, Davis JM et al. (2001). Cytokine changes after a marathon race. J Appl Physiol 91, 109-114.

Nieman DC, Johanssen LM, Lee JW, Arabatzis K (1990). Infectious episodes in runners before and after the Los Angeles Marathon. J Sports Med Phys Fitness 30, 316-328.

Nieman DC, Nehlsen-Cannarella SL, Fagoaga OR, Henson DA, Shannon M, Hjertman JM et al. (2000a). Immune function in female elite rowers and non-athletes. Br J Sports Med 34 181-187.

Nieman DC, Nehlsen-Cannarella SL, Fagoaga OR, Henson DA, Utter A, Davis JM et al. (1998a). Effects of mode and carbohydrate on the granulocyte and monocyte response to intensive, prolonged exercise. J Appl Physiol 84, 1252-1259.

Nieman DC, Nehlsen-Cannarella SL, Henson DA, Koch AJ, Butterworth DE, Fagoaga OR et al. (1998b). Immune response to exercise training and/or energy restriction in obese women. Med Sci Sports Exerc 30, 679-686.

Nieman DC, Peters EM, Henson DA, Nevines EI, Thompson MM (2000b). Influence of vitamin C supplementation on cytokine changes following an ultramarathon. J Interferon Cytokine Res 20, 1029-1035.

Nieman DC, Simandle S, Henson DA, Warren BJ, Suttles J, Davis JM et al. (1995). Lymphocyte proliferative response to 2.5 hours of running. Int J Sports Med 16, 404-409.

Palmer FM, Nieman DC, Henson DA, McAnulty SR, McAnulty L, Swick NS et al. (2003). Influence of vitamin C supplementation on oxidative and salivary IgA changes following an ultramarathon. Eur J Appl Physiol 89, 100-107.

Pedersen BK, Bruunsgaard H, Klokker M, Kappel M, MacLean DA, Nielsen HB et al. (1997). Exercise-induced immunomodulationpossible roles of neuroendocrine and metabolic factors. Int I Sports Med 18, S2-S7.

Pedersen BK, Helge JW, Richter EA, Rohde T, Kiens B (2000). Training and natural immunity: effects of diets rich in fat or carbohydrate. Eur J Appl Physiol 82, 98-102.

Peters EM, Bateman ED (1983). Ultramarathon running and upper respiratory tract infections. An epidemiological survey. $S$ Afr Med J 64, 582-584.

Peters EM, Anderson R, Nieman DC, Fickl H, Jogessar V (2001a). Vitamin C supplementation attenuates the increases in circulating cortisol, adrenaline and anti-inflammatory polypeptides following ultramarathon running. Int J Sports Med 22, 537-543.

Peters EM, Anderson R, Theron AJ (2001b). Attenuation of increase in circulating cortisol and enhancement of the acute phase protein response in vitamin C-supplemented ultramarathoners. Int J Sports Med 22, 120-126.

Peters EM, Goetzsche JM, Grobbelaar B, Noakes TD (1993). Vitamin C supplementation reduces the incidence of postrace symptoms of upper-respiratory-tract infection in ultramarathon runners. Am J Clin Nutr 57, 170-174.

Peters EM, Goetzsche JM, Joseph MC, Noakes TD (1996). Vitamin C as effective as combinations of anti-oxidant nutrients in reducing symptoms of upper respiratory tract infection (URTI) in ultramarathon runners. $S$ A Sportsmedicine 3, 23-27. 
Peters EM (1990). The effect of altitude on the incidence of upper respiratory tract infections following participation in ultramarathon events. SA Sports Med 5, 4-8.

Petersen EW, Ostrowski K, Ibfelt T, Richelle M, Offord E, HalkjaerKristensen J et al. (2001). Effect of vitamin supplementation on cytokine response and on muscle damage after strenuous exercise. Am J Physiol Cell Physiol 280, C1570-C1575.

Prasad JS (1980). Effect of vitamin E supplementation on leukocyte function. Am J Clin Nutr 33, 606-608.

Radak Z, Pucsuk J, Boros S, Josfai L, Taylor AW (2000). Changes in urine 8-hydroxydeoxyguanosine levels of super-marathon runners during a four-day race period. Life Sci 66, 1763-1767.

Rennie MJ, Edwards RH, Krywawych S, Davies CT, Halliday D, Waterlow JC et al. (1981). Effect of exercise on protein turnover in man. Clin Sci (Lond) 61, 627-639.

Robinson KA, Dickersin K (2002). Development of a highly sensitive search strategy for the retrieval of reports of controlled trials using PubMed. Int J Epidemiol 31, 150-153.

Robson PJ, Bouic PJ, Myburgh KH (2003). Antioxidant supplementation enhances neutrophil oxidative burst in trained runners following prolonged exercise. Int J Sport Nutr Exerc Metab 13, 369-381.

Rohde T, Asp S, MacLean DA, Pedersen BK (1998). Competitive sustained exercise in humans, lymphokine activated killer cell activity, and glutamine - an intervention study. Eur J Appl Physiol Occup Physiol 78, 448-453.

Scharhag J, Meyer T, Gabriel HH, Auracher M, Kindermann W (2002). Mobilization and oxidative burst of neutrophils are influenced by carbohydrate supplementation during prolonged cycling in humans. Eur J Appl Physiol 87, 584-587.

Shinkai S, Kurokawa Y, Hino S, Hirose M, Torii J, Watanabe S et al. (1993). Triathlon competition induced a transient immunosuppressive change in the peripheral blood of athletes. J Sports Med Phys Fitness 33, 70-78.

\section{Appendix A: Search strategy}

Database: SPORTDiscus 1830 to May 2005; EBM Reviews Cochrane Central Register of Controlled Trials 2nd Quarter 2005; EBM Reviews - Cochrane Database of Systematic Reviews 2nd Quarter 2005; Ovid MEDLINE(R) In-Process \& Other NonIndexed Citations and Ovid MEDLINE(R) 1966 to Present

Search strategy:

randomi[z]ed controlled trial.pt. (392250)

controlled clinical trial.pt. (134553)

Randomi[z]ed Controlled Trials/ (41104)

Random Allocation/ (72830)

Double-Blind Method/ (147455)

Single-Blind Method/ (14248)

or/1-6 (593956)

Animals/ not Human/ (2863905)

7 not 8 (570442)

clinical trial.pt. (657885)

exp Clinical Trials/ (201366)

(clinic\$ adj25 trial\$).tw. (149833)

((singl\$ or doubl\$ or trebl\$ or tripl\$) adj (mask\$ or blind\$)).tw. (173831)

Placebos/ (39895)
Singh A, Papanicolaou DA, Lawrence LL, Howell EA, Chrousos GP, Deuster PA (1999). Neuroendocrine responses to running in women after zinc and vitamin E supplementation. Med Sci Sports Exerc 31, 536-542.

Starkie RL, Angus DJ, Rolland J, Hargreaves M, Febbraio MA (2000). Effect of prolonged, submaximal exercise and carbohydrate ingestion on monocyte intracellular cytokine production in humans. J Physiol 528, 647-655.

Starkie RL, Arkinstall MJ, Koukoulas I, Hawley JA, Febbraio MA (2001). Carbohydrate ingestion attenuates the increase in plasma interleukin-6, but not skeletal muscle interleukin-6 mRNA, during exercise in humans. J Physiol 533, 585-591.

Sterne JA, Egger M, Smith GD (2001). Systematic reviews in health care: Investigating and dealing with publication and other biases in meta-analysis. BMJ 323, 101-105.

Tauler P, Aguilo A, Fuentespina E, Tur JA, Pons A (2002). Diet supplementation with vitamin $\mathrm{E}$, vitamin $\mathrm{C}$ and beta-carotene cocktail enhances basal neutrophil antioxidant enzymes in athletes. Pflugers Arch 443, 791-797.

Tauler P, Gimeno I, Aguilo A, Guix MP, Pons A (1999). Regulation of erythrocyte antioxidant enzyme activities in athletes during competition and short-term recovery. Pflugers Arch 438, $782-787$.

Toft AD, Thorn M, Ostrowski K, Asp S, Moller K, Iversen S et al. (2000). N-3 polyunsaturated fatty acids do not affect cytokine response to strenuous exercise. I Appl Physiol 89, 2401-2406.

Walsh NP, Blannin AK, Bishop NC, Robson PJ, Gleeson M (2000). Effect of oral glutamine supplementation on human neutrophil lipopolysaccharide-stimulated degranulation following prolonged exercise. Int J Sport Nutr Exerc Metab 10, 39-50.

Whitehead A, Whitehead J (1991). A general parametric approach to the meta-analysis of randomized clinical trials. Stat Med 10 $1665-1677$.

placebo\$.tw. (178494)

random\$.tw. (513086)

Research Design/ (42074)

(latin adj square).tw. (3033)

or/10-18 (1072000)

19 not 8 (1015274)

20 not $9(455654)$

or/9-20 (1082822)

(immun $\$$ adj5 (athl\$ or nutrit\$ or exercise)).mp. $[\mathrm{mp}=\mathrm{ti}$, ot, ab, nm, hw, sh, kw, tx, ct, da, fa, ce, fc, fd] (4336)

(nutrit\$ adj5 (athl\$ or immun\$ or exercise)).mp. $[\mathrm{mp}=\mathrm{ti}$, ot, ab, nm, hw, sh, kw, tx, ct, da, fa, ce, fc, fd] (6651) (exercise $\$$ adj5 (athl\$ or immun\$ or nutrit\$)).mp. [mp $=$ ti, ot, ab, nm, hw, sh, kw, tx, ct, da, fa, ce, fc, fd] (8929)

(exercise $\$$ adj5 (carbohydrat\$ or glutamine or vitam\$ or immun $\$$ or nutrit\$)).mp. [mp = ti, ot, ab, nm, hw, kw, sh, tx, ct, fc, da, fa, ce, fd] (7568)

or/23-26 (15829)

$($ athl\$ and immun\$).mp. [mp = ti, ot, ab, nm, hw, kw, sh, tx, ct, fc, da, fa, ce, fd] (1528)

and/27-28 (795)

and/22,29 (105) 
Appendix B: Quality rating of included studies

\begin{tabular}{|c|c|c|c|c|c|c|c|c|c|c|c|c|c|c|c|c|c|c|c|c|c|}
\hline Study & Total & & & & & 3 & 4 & 5 & 6 & & & 7 & & & & 8 & & 9 & 10 & & \\
\hline Peters et al. (1993) & 11 & 0.5 & 1 & 0.5 & 0 & 0 & 2 & 0 & 0 & 0.5 & 0.5 & 0.5 & 0.5 & 1 & 0.5 & 0.5 & 0.5 & 1 & 0.5 & 0.5 & \\
\hline Peters et al. (1996) & 11 & 0.5 & 1 & 0.5 & 0 & 0 & 2 & 0 & 0 & 0.5 & 0.5 & 0.5 & 0.5 & 1 & 0.5 & 0.5 & 0.5 & 1 & 0.5 & 0.5 & 0.5 \\
\hline Castell et al. (1996) & 8.5 & 0.5 & 1 & 0 & 0 & 0 & 2 & 0 & 0 & 0.5 & 0.5 & 0.5 & 0.5 & 0.5 & 0.5 & 0.5 & 0.5 & 0 & 0 & 0.5 & 0.5 \\
\hline Nieman et al. (1997a) & 9 & 1 & 1 & 0.5 & 0.5 & 0 & 2 & 0 & 0 & 0.5 & 0.5 & 0.5 & 0.5 & 0.5 & 0.5 & 0.5 & 0.5 & 0 & 0 & 0 & 0 \\
\hline Nieman et al. (1997b) & 7.5 & 0 & 1 & 0.5 & 0 & 0 & 1 & 0 & 0 & 0.5 & 0.5 & 0.5 & 0.5 & 0.5 & 0.5 & 0.5 & 0.5 & 0 & 0 & 0.5 & 0.5 \\
\hline Nieman et al. (1997c) & 9 & 1 & 1 & 0.5 & 0.5 & 0 & 2 & 0 & 0 & 0.5 & 0.5 & 0.5 & 0.5 & 0.5 & 0.5 & 0.5 & 0.5 & 0 & 0 & 0 & 0 \\
\hline Castell et al. (1997) & 5.0 & 0 & 1 & 0 & 0 & 0 & 0 & 0 & 0 & 0.5 & 0.5 & 0.5 & 0.5 & 0.5 & 0.5 & 0.5 & 0.5 & 0 & 0 & 0 & 0 \\
\hline Nehlsen-Cannarella et al. (1997) & 8 & 0 & 1 & 0.5 & 0.5 & 0 & 2 & 0 & 0 & 0.5 & 0.5 & 0.5 & 0.5 & 0.5 & 0.5 & 0.5 & 0.5 & 0 & 0 & 0 & 0 \\
\hline Mero (1997) & 7 & 0 & 1 & 0 & 0 & 0 & 2 & 0 & 0 & 0.5 & 0.5 & 0.5 & 0.5 & 0.5 & 0.5 & 0.5 & 0.5 & 0 & 0 & 0 & 0 \\
\hline Rohde et al. (1998) & 6.5 & 0.5 & 1 & 0.5 & 0.5 & 0 & 1 & 0 & 0 & 0.5 & 0.5 & 0.5 & 0.5 & 0 & 0.5 & 0.5 & 0 & 0 & 0 & 0 & 0 \\
\hline Henson et al. (1998) & 9 & 1 & 1 & 0.5 & 0.5 & 0 & 2 & 0 & 0 & 0.5 & 0.5 & 0.5 & 0.5 & 0.5 & 0.5 & 0.5 & 0.5 & 0 & 0 & 0 & 0 \\
\hline Henson et al. (1999) & 7.5 & 0 & 1 & 0 & 0.5 & 0 & 2 & 0 & 0 & 0.5 & 0.5 & 0.5 & 0.5 & 0.5 & 0.5 & 0.5 & 0.5 & 0 & 0 & 0 & 0 \\
\hline Bouic et al. (1999) & 8 & 0.5 & 1 & 0 & 0 & 0 & 2 & 0 & 0 & 0.5 & 0.5 & 0.5 & 0.5 & 0.5 & 0.5 & 0.5 & 0 & 1 & 0 & 0 & 0 \\
\hline Himmelstein et al. (1998) & 8.5 & 0.5 & 1 & 0.5 & 0 & 0 & 2 & 0 & 0 & 0.5 & 0.5 & 0.5 & 0.5 & 0.5 & 0 & 0 & 0.5 & 1 & 0.5 & 0.5 & 0.5 \\
\hline Bishop et al. (1999) & 6 & 0 & 1 & 0 & 0.5 & 0 & 1 & 0 & 0 & 0.5 & 0.5 & 0.5 & 0.5 & 0 & 0.5 & 0.5 & 0.5 & 0 & 0 & 0 & 0 \\
\hline Singh et al. (1999) & 7.5 & 0.5 & 1 & 0 & 0.5 & 0 & 2 & 0 & 0 & 0.5 & 0.5 & 0.5 & 0.5 & 0 & 0.5 & 0.5 & 0.5 & 0 & 0 & 0 & 0 \\
\hline Krzywkowski et al. (2001a) & 6.5 & 0 & 1 & 0.5 & 0.5 & 0 & 1 & 0 & 0 & 0.5 & 0.5 & 0.5 & 0.5 & 0 & 0.5 & 0.5 & 0.5 & 0 & 0 & 0 & 0 \\
\hline Krzywkowski et al. (2001b) & 6.5 & 0 & 1 & 0.5 & 0.5 & 0 & 1 & 0 & 0 & 0.5 & 0.5 & 0.5 & 0.5 & 0 & 0.5 & 0.5 & 0.5 & 0 & 0 & 0 & 0 \\
\hline Walsh et al. (2000) & 6 & 0 & 1 & 0 & 0.5 & 0 & 1 & 0 & 0 & 0.5 & 0.5 & 0.5 & 0.5 & 0 & 0.5 & 0.5 & 0.5 & 0 & 0 & 0 & 0 \\
\hline Toft et al. (2000) & 6 & 0.5 & 1 & 0.5 & 0.5 & 0 & 0 & 0 & 0 & 0.5 & 0.5 & 0.5 & 0.5 & 0 & 0.5 & 0.5 & 0.5 & 0 & 0 & 0 & 0 \\
\hline Bassit et al. (2000) & 6 & 0.5 & 0.5 & 0 & 0 & 0 & 0 & 0 & 0 & 0.5 & 0.5 & 0.5 & 0.5 & 0.5 & 0.5 & 0.5 & 0.5 & 0 & 0 & 0.5 & 0.5 \\
\hline Nieman et al. (2000b) & 7.5 & 0 & 1 & 0.5 & 0 & 0 & 1 & 0 & 0 & 0.5 & 0.5 & 0.5 & 0.5 & 0.5 & 0.5 & 0.5 & 0.5 & 0 & 0 & 0.5 & 0.5 \\
\hline Starkie et al. (2000) & 7 & 0 & 1 & 0.5 & 0.5 & 0 & 1 & 0 & 0 & 0.5 & 0.5 & 0.5 & 0.5 & 0.5 & 0.5 & 0.5 & 0.5 & 0 & 0 & 0 & 0 \\
\hline Bishop et al. (2001b) & 6.5 & 0 & 1 & 0 & 0.5 & 0 & 1 & 0 & 0 & 0.5 & 0.5 & 0.5 & 0.5 & 0.5 & 0.5 & 0.5 & 0.5 & 0 & 0 & 0 & 0 \\
\hline Starkie et al. (2001) & 7 & 0 & 1 & 0.5 & 0.5 & 0 & 1 & 0 & 0 & 0.5 & 0.5 & 0.5 & 0.5 & 0.5 & 0.5 & 0.5 & 0.5 & 0 & 0 & 0 & 0 \\
\hline Nieman et al. (2001) & 9 & 0.5 & 1 & 0.5 & 0 & 0 & 2 & 0 & 0 & 0.5 & 0.5 & 0.5 & 0.5 & 0.5 & 0.5 & 0.5 & 0.5 & 0.5 & 0.5 & 0 & 0 \\
\hline Koch et al. (2001) & 7 & 0 & 1 & 0 & 0 & 0 & 2 & 0 & 0 & 0.5 & 0.5 & 0.5 & 0.5 & 0.5 & 0.5 & 0.5 & 0.5 & 0 & 0 & 0 & 0 \\
\hline Peters et al. (2001b) & 7.5 & 0.5 & 0.5 & 0.5 & 0 & 0 & 1 & 0 & 0 & 0.5 & 0.5 & 0.5 & 0.5 & 0.5 & 0.5 & 0.5 & 0.5 & 0.5 & 0.5 & 0 & 0 \\
\hline Peters et al. (2001a) & 7.5 & 0.5 & 0.5 & 0.5 & 0 & 0 & 1 & 0 & 0 & 0.5 & 0.5 & 0.5 & 0.5 & 0.5 & 0.5 & 0.5 & 0.5 & 0.5 & 0.5 & 0 & 0 \\
\hline Petersen et al. (2001) & 8.5 & 0 & 1 & 0.5 & 0.5 & 0 & 2 & 0 & 0 & 0.5 & 0.5 & 0.5 & 0.5 & 0.5 & 0.5 & 0.5 & 0.5 & 0.5 & 0 & 0 & 0 \\
\hline Krause et al. (2001) & 7.5 & 01 & 1 & 0.5 & 0 & 0 & 1 & 0 & 0 & 0.5 & 0.5 & 0.5 & 0.5 & 0.5 & 0.5 & 0.5 & 0.5 & 0.5 & 0 & 0 & 0 \\
\hline Bassit et al. (2002) & 6 & 0.5 & 0.5 & 0 & 0 & 0 & 0 & 0 & 0 & 0.5 & 0.5 & 0.5 & 0.5 & 0.5 & 0.5 & 0.5 & 0.5 & 0 & 0 & 0.5 & \\
\hline Bishop et al. (2002) & 6.5 & 0 & 1 & 0 & 0.5 & 0 & 1 & 0 & 0 & 0.5 & 0.5 & 0.5 & 0.5 & 0.5 & 0.5 & 0.5 & 0.5 & 0 & 0 & 0 & 0 \\
\hline Tauler et al. (2002) & 5.5 & 0.5 & 0.5 & 0.5 & 0 & 0 & 2 & 0 & 0 & 0.5 & 0.5 & 0.5 & 0.5 & 0 & 0 & 0 & 0 & 0 & 0 & 0 & 0 \\
\hline Bacurau et al. (2002) & 7.5 & 0 & 1 & 0 & 0.5 & 0 & 2 & 0 & 0 & 0.5 & 0.5 & 0.5 & 0.5 & 0.5 & 0.5 & 0.5 & 0.5 & 0 & 0 & 0 & 0 \\
\hline Nieman et al. (2002b) & 8.5 & 0.5 & 1 & 0.5 & 0.5 & 0 & 2 & 0 & 0 & 0.5 & 0.5 & 0.5 & 0.5 & 0.5 & 0.5 & 0.5 & 0.5 & 0 & 0 & 0 & 0 \\
\hline Scharhag et al. (2002) & 8 & 0 & 1 & 0 & 0.5 & 0 & 2 & 0 & 0 & 0.5 & 0.5 & 0.5 & 0.5 & 0.5 & 0.5 & 0.5 & 0.5 & 0 & 0.5 & 0 & 0 \\
\hline Lancaster et al. (2003) & 6 & 0.5 & 1 & 0.5 & 0.5 & 0 & 0 & 0 & 0 & 0.5 & 0.5 & 0.5 & 0.5 & 0 & 0.5 & 0.5 & 0.5 & 0 & 0 & 0 & 0 \\
\hline Palmer et al. (2003) & 8.5 & 0.5 & 1 & 0.5 & 0.5 & 0 & 2 & 0 & 0 & 0.5 & 0.5 & 0.5 & 0.5 & 0.5 & 0.5 & 0.5 & 0.5 & 0 & 0 & 0 & 0 \\
\hline Robson et al. (2003) & 7.5 & 0.5 & 1 & 0 & 0.5 & 0 & 2 & 0 & 0 & 0.5 & 0.5 & 0.5 & 0.5 & 0 & 0.5 & 0.5 & 0.5 & 0 & 0 & 0 & 0 \\
\hline Nieman et al. (2003) & 5.5 & 0.5 & 1 & 0 & 0.5 & 0 & 0 & 0 & 0 & 0.5 & 0.5 & 0.5 & 0.5 & 0 & 0.5 & 0.5 & 0.5 & 0 & 0 & 0 & 0 \\
\hline Chan et al. (2003) & 7 & 0 & 1 & 0 & 0 & 0 & 2 & 0 & 0 & 0.5 & 0.5 & 0.5 & 0.5 & 0.5 & 0.5 & 0.5 & 0.5 & 0 & 0 & 0 & 0 \\
\hline Hiscock et al. (2003) & 7 & 0 & 1 & 0 & 0.5 & 0 & 2 & 0 & 0 & 0.5 & 0.5 & 0.5 & 0.5 & 0 & 0.5 & 0.5 & 0.5 & 0 & 0 & 0 & 0 \\
\hline Bishop et al. (2003) & 6.5 & 0 & 1 & 0 & 0.5 & 0 & 1 & 0 & 0 & 0.5 & 0.5 & 0.5 & 0.5 & 0.5 & 0.5 & 0.5 & 0.5 & 0 & 0 & 0 & 0 \\
\hline Nieman et al. (2004) & 7 & 0.5 & 1 & 0.5 & 0 & 0 & 1 & 0 & 0 & 0.5 & 0.5 & 0.5 & 0.5 & 0.5 & 0.5 & 0.5 & 0.5 & 0 & 0 & 0 & 0 \\
\hline
\end{tabular}

$1=$ Athletes selection: all eligible athletes with number of, and reason for, exclusions given (1); attempt to do so, but reasons for failure and exclusion not given (0.5); selected athletes/eligible athletes not described (0); homogeneity of type-of-sports practiced: yes (1); no (0.5); not given (0). 2 = Athletes characteristics at baseline: Similar distribution between groups reported (0.5), not reported/not applicable (0); basal oxygen consumption reported (0.5), not reported (0). $3=$ Randomisation: concealed randomisation (computer, centralised, etc.) (2); potentially manipulable (sealed envelope, date of admission, medical records, birth date, etc.) (1); [can't tell/unknown/unclear] (0). $4=$ Blinding: double blinded (research team/athletes) (2); single blinded (1); unblinded/can't tell (0). 5 = Intentionto treat analysis: reported (1), not reported (0); $6=$ Allocation concealment: adequate (2), unclear (1), inadequate $(0.5)$, allocation concealment was not used $(0)$. $7=$ Intervention: nutritional supplement described explicitly - yes (0.5), no (0); dosing regimen (dose, frequency) reported (0.5), not reported (0); duration of treatment reported (0.5), not reported (0); placebo reported (0.5), not reported (0); dietary intake control done (1), not done (0.5) not reported (0). 8 = Explicit description of type of exercise performed: yes $(0.5)$, no (0); exercise regimen (amount, frequency) reported (0.5), not reported (0); duration of exercise reported (0.5), not reported ( 0$) .9=$ Withdrawal: described number and reason for withdrawal ( 1$)$; described one of above $(0.5)$; described neither $(0)$. $10=$ Adherence to protocol: reported (0.5), not reported (0). 11 = Infections after exercise: reported: yes (0.5), no (0); direct medical examination (1), indirect questionnaire/interview (0.5), not done/ not applicable (0). 